\title{
DISTRIBUTION AND NEUROCHEMICAL CHARACTERIZATION OF NEURONS EXPRESSING GIRK CHANNELS IN THE RAT BRAIN
}

\section{LAURA SAENZ DEL BURGO ${ }^{1}$, ROSER CORTES ${ }^{2}$, GUADALUPE MENGOD ${ }^{2}$, JON}

ZARATE $^{3}$, ENRIQUE ECHEVARRIA ${ }^{3}$ and JOAN SALLES ${ }^{1}$

${ }^{1}$ Department of Pharmacology and ${ }^{3}$ Department of Physiology. Faculty of Pharmacy, University of the Basque Country UPV-EHU. Paseo de la Universidad 7, E-01006 Vitoria, Spain

${ }^{2}$ Department of Neuropharmacology, Instituto de Investigaciones Biomédicas de Barcelona, CSIC-IDIBAPS. Rosselló 161, E-08036 Barcelona, Spain

Abbreviated title: GIRK channels in different neuronal populations

Name of associate editor: Prof. CLIFFORD B. SAPER

Key words: GIRK1-3; vesicular glutamate transporter; GAD; ChAT; serotonin transporter; 5- $\mathrm{HT}_{1 \mathrm{~A}}$ receptor

Corresponding author:

Laura Saenz del Burgo

Department of Pharmacology, Faculty of Pharmacy, University of the Basque Country UPV-EHU

C/ Paseo de la Universidad 7

E-01006 Vitoria, Spain.

Phone numbers: +34 636809928 - +34945013893

Fax number: +34945013327

E-mail address: laura.saenzdelburgo@ehu.es

Support and grants: This work was supported by grants SAF2004-02784 and SAF2006-10243 from the Spanish Ministry of Education and grants Saiotek-PE06UN12 and IT-261-07 from the Basque Government. Laura Saenz del Burgo was recipient of a fellowship from the Basque Government. 


\section{ABSTRACT}

G-protein inwardly rectifying potassium (GIRK) channels mediate the synaptic actions of numerous neurotransmitters in the mammalian brain and play an important role in the regulation of neuronal excitability in most brain regions through activation of various G-protein coupled receptors such as the serotonin $5-\mathrm{HT}_{1 \mathrm{~A}}$ receptor. In this report we describe the localization of GIRK1, GIRK2 and GIRK3 subunits and 5-HT $1 \mathrm{~A}$ receptor in the rat brain, as assessed by immunohistochemistry and in situ hybridization. We also analyze the co-expression of GIRK subunits with the 5-HT1A receptor and cell markers of glutamatergic, GABAergic, cholinergic and serotonergic neurons in different brain areas by double-label in situ hybridization. The three GIRK subunits are widely distributed throughout the brain, with an overlapping expression in cerebral cortex, hippocampus, paraventricular nucleus, supraoptic nucleus, thalamic nuclei, pontine nuclei and granular layer of the cerebellum. Double-labeling experiments show that GIRK subunits are present in most of the 5-HT $1 \mathrm{~A}$ receptorexpressing cells in hippocampus, cerebral cortex, septum and dorsal raphe nucleus. Similarly, GIRK mRNA subunits are found in glutamatergic and GABAergic neurons in hippocampus, cerebral cortex and thalamus, in cholinergic cells in the nucleus of vertical limb of the diagonal band and in serotonergic cells in the dorsal raphe nucleus. These results provide a deeper knowledge of the distribution of GIRK channels in different cell subtypes in the rat brain and might help to elucidate their physiological roles and to evaluate their potential involvement in human diseases. 


\section{INTRODUCTION}

Inwardly rectifying potassium channels have dominant control of the membrane potential of mammalian neurons, and modulation of their activity can profoundly influence neuronal excitability (Jan and Jan, 1997). A major signal transduction mechanism in neurobiology is the direct coupling of metabotropic receptors to ion channels by a membrane-delimited pathway that does not involve cytoplasmic intermediates (Nicoll, 1988; Neer, 1995). Inwardly rectifying potassium channels fall into seven subfamilies, and include a subfamily designated as Kir3 that is directly coupled to heterotrimeric G-proteins and mediates the effect of activated metabotropic receptors (Dascal, 1997; Yamada et al., 1998). Activation of metabotropic receptors coupled to $G_{i / o}$ proteins catalyses the release of $G \beta y$ subunits and directly interact with Kir3 channels to increase their open probability (Logothetis et al., 1987; Krapivinsky et al., 1995; Wickman and Clapham, 1995). This subfamily of inward rectifiers, also known as the $G$ protein-regulated inwardly rectifying potassium (GIRK) channels, is composed of four members designated GIRK1-4 (Dascal, 1997). GIRK channels are tetramers and hence could exist as homo- or heteromeric complexes (Yang et al., 1995). Although the different GIRK subunits are regulated differentially by a variety of intracellular factors, reports indicate that these channels require membrane phosphatidylinositol-4,5-bisphosphate $\left(\mathrm{PIP}_{2}\right)$ for activity (Sui et al., 1998; Huang et al., 1998; Ho and Murrell-Lagnado, 1999). The levels of $\mathrm{PIP}_{2}$ can be changed and per se acts as a novel signal to regulate GIRK channels. Moreover, the functional dependence of $\mathrm{G} \beta \mathrm{y}$ signalling on $\mathrm{PIP}_{2}$ predicts the possible cross-talk of different metabotropic receptors. In fact, GIRK channels are inhibited by activation of metabotropic receptors coupled to $G_{q / 11}$ proteins and fosfolipase $C-\beta$ via local $P_{P} P_{2}$ depletion (Cho et al., 2005).

In addition to their major physiological role in synaptic transmission and regulation of membrane potential, GIRK proteins have been shown to be potential sites for genetic mutations inducing neuronal cell death. Our understanding of the development, maintenance and degeneration of mammalian nervous systems has been greatly facilitated by examination of naturally occurring ("weaver mouse") and engineered ("Ts65Dn mouse") neurological mouse mutants at chromosome 16 (Davisson et al., 1990; Patil et al., 1995). Homozygous weaver (wv) mutations result in aberrant postnatal development and death of several classes of neurons. Compelling evidence indicates that the weaver phenotype results from a point mutation in the 
sequence of the gene coding for the GIRK2 protein (Patil et al., 1995). The expression of GIRK2wv in heterologous systems has electrophysiological consequences (Slesinger et al., 1997; Rossi et al., 1998). A hypothesis hold that the mutated channel is inactive and that subsequent lack of regulation of membrane potential leads to excessive $\mathrm{Ca}^{+2}$ entry and death (Rossi et al., 1998). Mice with segmental trisomy 16 (Ts65Dn) which have triplication of a region of mouse chromosome 16 homologous to the Down syndrome critical region in human chromosome 21 , demonstrate behavioural abnormalities related to spatial learning and memory (Davisson et al., 1990). Evidence demonstrating alterations in signal transduction pathways through adenylyl cyclases and phospholipase C- $\beta$ have been reported and interestingly, all GIRK2 splicing isoforms examined are expressed at higher levels in the Ts65Dn in comparison to the diploid brain mouse (Dierssen et al., 1997; Ruiz de Azua et al., 2001; Harashima et al., 2006). Importantly, elevated levels of GIRK2 protein correlated with elevated levels of GIRK1 in several regions of the Ts65Dn mouse (Harashima et al., 2006). These results hold the current view of the GIRK2 subunits as an essential component that determines the surface localization of GIRK1 subunits. Therefore, a better knowledge of the coexpression pattern of GIRK proteins in the brain could help to elucidate their potential role in the genesis of or susceptibility to various neurodegenerative and developmental disorders.

Three GIRK channel subunits (GIRK1-GIRK3) exhibit broad and overlapping distributions in the central nervous system (CNS), whereas the fourth subunit (GIRK4) is found primarily in the heart (Kobayashi et al., 1995; Krapivinsky et al., 1995; Karschin et al., 1996; Chan et al., 1997). Formerly, the overlapping distributions of GIRK subunits in the CNS suggested that channels formed by multiple subunit combinations could contribute to neuronal channel content. An area of research now becoming appreciated is the process by which ion-channel proteins are translocated to the cell surface (Ma and Jan, 2002). Several groups have reported specific trafficking signals embedded within the ion channels, that is, aminoacid sequence motifs that are crucial for channel membrane-targetting and coassembly (Deutsch, 2002). Studies on GIRK channels have provided some clues to the complexity with which ion channels are processed and targeted to the membrane (Woodward et al., 1997; Ma et al., 2001). GIRK1 does not form functional channels when expressed alone, due to defects in membrane targeting (Chan et al., 1996; Woodward et al., 1997; Mirshahi and Logothetis, 2004). GIRK2 and GIRK4, both of which can function as homomers contain 
endoplasmic reticulum (ER) export signals and reach the surface efficiently (Kennedy et al., 1999). However, although homomeric GIRK2 and GIRK4 channels have been found in native tissues exogenously expressed homomers of these channels give very brief and poorly resolved open-time kinetics that are different from native channels (Chan et al., 1996; Corey and Clapham, 1998). Importantly, both GIRK2 and GIRK4 can recruit GIRK1, greatly increasing its surface expression and those results in highly active channels that are indistinguishable from native channels (Krapivinsky et al., 1995; Chan et al., 1997; Woodward et al., 1997; Kennedy et al., 1999). Interestingly, it has been showed that GIRK2/GIRK3 heteromers have some activity, but showing reduced $\mathrm{G} \beta$ y sensitivity compared to other heteromers containing GIRK1 subunits (Jelacic et al., 2000). Comparison of the sequences of GIRK3 and other GIRK family members suggests that other differences might have functional consequences as well. For example, Glu ${ }^{35}$ in GIRK3 is replaced by $\mathrm{His}^{64}$ (the equivalent position) in GIRK4, and $\mathrm{His}^{64}$ interacts with Gßy (He et al., 2002). Whereas GIRK3 has Asp ${ }^{165}$, other inward rectifiers contain a lysine residue that is involved in interacting with $\mathrm{PIP}_{2}$ (Lopes et al., 2002). A most intriguing finding is that GIRK3, not only lacks an ER export signal, but in addition, GIRK3 contains a lysosomal targeting signal (Ma et al., 2002). Co-expression of GIRK3 with GIRK1 and GIRK2 leads to reduced expression of GIRK1 at the cell surface, and it has been proposed that GIRK3 target functional neuronal GIRK channels (GIRK1/GIRK2 heteromers and GIRK2 homomers) to lysosomal degradation pathways (Ma et al., 2002). Therefore, although the current view is that GIRK1/GIRK2 heteromers are considered the prototypical GIRK channel in the CNS, the functional differences along with the unique trafficking characteristics of GIRK3, could open a new scenario for regulating the density of functional GIRK1/GIRK2 (or GIRK1/GIRK4) channels on cell surface simply controlling the amount of GIRK3 expressed, and therefore, the number of GIRK1/GIRK2 channels on the plasma membrane (Leaney, 2003).

Despite the importance of GIRK3, and in contrast to the extensive studies of GIRK mRNA distribution, little is known about the co-localization of GIRK subunits mRNA at cellular level in the brain. In this report we describe the distribution (protein and mRNA) and co-localization (mRNA) of GIRK(1-3) subunits and 5-HT1A serotonin receptors in the adult rat brain. We choose the $5-\mathrm{HT}_{1 \mathrm{~A}}$ receptor for further anatomical co-localization with GIRK channels because extensive functional studies of GIRKmediated functions of $5-\mathrm{HT}_{1 \mathrm{~A}}$ receptors have been performed. In fact, it has been long 
known that the $5-\mathrm{HT}_{1 \mathrm{~A}}$ serotonin receptor can stimulate the opening of GIRK channels in neurons (Andrade and Nicoll, 1987; Colino and Halliwell, 1987; Zgombick et al., 1989; Penington et al., 1993). Again, there exists limited knowledge on the coexpression of $5-\mathrm{HT}_{1 \mathrm{~A}}$ receptor and GIRK subunits on defined cell subtypes of rat brain. The second aim of the study was to examine in detail the relationships of GIRK(1-3) mRNA positive neurons to glutamatergic, GABAergic and serotonergic neurons by in situ hybridization. 


\section{MATERIALS AND METHODS}

\section{ANIMALS}

Male albine Sprague-Dawley rats weigh 250-300 g were obtained from Iffa Credo (Lyon, France). Animals were kept in a controlled environment (12 h light-dark cycle, lights on at 08:00 $\mathrm{h}$, and $22 \pm 2{ }^{\circ} \mathrm{C}$ room temperature) with food and water provided ad libitum. Rats were carefully handled following the European Union regulations (O.J. of E.C. L358/1 18/12/1986).

\section{WESTERN BLOT STUDIES OF GIRK SUBUNITS}

After killing animals by decapitation, their brains were immediately removed and cerebral cortices were dissected out on ice and stored at $-80^{\circ} \mathrm{C}$. The preparation of membranes from rat cerebral cortex samples was essentially as previously described for rat and human brain tissues (Garro et al., 2001; Salles et al., 2001). Western blot studies were performed as previously reported for GIRK subunits in rodent brain with minor modifications (Liao et al., 1996; Inanobe et al., 1999; Torrecilla et al., 2002). Briefly, plasmatic membrane proteins were solubilized in a sample buffer $(2.2 \%(\mathrm{w} / \mathrm{v})$ sodium dodecylsulphate [SDS], 6.6\% (v/v) 2-mercaptoethanol, 11\% (v/v) glycerol and $125 \mathrm{mM}$ Tris- $\mathrm{HCl}, \mathrm{pH} 7.5)$, resolved by electrophoresis in 10\% SDS-polyacrylamide gels and then transferred to polyvinylidine difluoride membranes (Amersham Pharmacia, Madrid, Spain). Blots were blocked in 5\% non-fat dry milk/phosphatebuffered saline for $1 \mathrm{~h}$, and incubated overnight with anti-GIRK1, GIRK2 or GIRK3 antibodies. GIRK1 protein was detected using a rabbit polyclonal antiserum (1:7000; Alomone Labs, Jerusalem, Israel; cat. No. APC-005) raised against the synthetic peptide corresponding to 437-501 residues of mouse GIRK1 protein (acc. No. P35562). GIRK2 protein was detected using a rabbit polyclonal antiserum (1:250; Alomone Labs; cat. No. APC-006) raised against the synthetic peptide corresponding to 374-414 residues of mouse GIRK2 protein (acc. No. P48542). GIRK3 protein was detected using a rabbit polyclonal antiserum (1:250; Alomone Labs; cat. No. APC-038) raised against the synthetic peptide corresponding to 344-361 residues of mouse GIRK3 protein (acc. No. Q63511). Blots were washed and incubated with secondary antibodies (donkey anti-rabbit IgG; Amersham Pharmacia, product code NA934) conjugated to horseradish peroxidase diluted to 1:4000 in blocking buffer for $2 \mathrm{~h}$ at 
room temperature. Immunoreactive bands were visualized with the enhanced chemiluminiscence (ECL) system (Amersham Pharmacia). Film analysis was conducted by quantitative densitometry. Each gel contained a prestained broad-range protein ladder to measure molecular masses of individual bands.

\section{IMMUNOHISTOCHEMISTRY}

\section{Tissue preparation}

Animals were anaesthetized intraperitoneally with 15\% choral hydrate (Sigma) and perfused transcardially under deep anaesthesia with saline in $50 \mathrm{mM}$ phosphate buffer ( $\mathrm{pH}$ 7.4), followed by $4 \%$ paraformaldehyde (Sigma). Brains were removed, kept immersed in the same fixative medium overnight and stored at $4{ }^{\circ} \mathrm{C}$ for 2 days in $0.1 \mathrm{M}$ phosphate buffer containing 30\% sucrose. Tissue sections, $30 \mu \mathrm{m}$ thick, were cut using a microtome-cryostat (Cryocut 3.000, Leica, Germany) with a stereotaxic atlas guide (Paxinos and Watson, 1998).

\section{Immunohistochemistry procedure}

The antigens, GIRK1, GIRK2, GIRK3 subunits and 5-HT $1 \mathrm{~A}$ receptor, were detected by immunohistochemistry using the avidin-peroxidase method with 3,3'diaminobenzidine (DAB) as chromogen. Following reduction of endogenous peroxidases with $1 \%$ hydrogen peroxide (Sigma) and blocking of nonspecific background staining with $5 \%$ normal goat serum (NGS) (Sigma), the sections were incubated with the following immunoreagents: 1) primary antisera: commercially obtained polyclonal antibodies used were rabbit anti-GIRK1, GIRK2 or GIRK3 channels (diluted to 1:100, 1:300 and 1:300, respectively; Alomone Labs; cat. No.s APC-005, APC-006, APC-038) or guinea pig anti-5- $\mathrm{HT}_{1 \mathrm{~A}}$ receptor (1:1000, raised against a synthetic peptide -PPPKKSLNGQPGSGD- corresponding to a region located in the large third intracellular loop of the rat and mouse $5-\mathrm{HT}_{1 \mathrm{~A}}$ receptor protein; Chemicon Intl. Inc., Temula, CA; cat. No. AB5406); 2) goat anti-rabbit biotin-conjugated immunoglobulines (1:200; Chemicon Intl. Inc.; cat. No. AP132B) for GIRK1, GIRK2 and GIRK3, or goat anti-guinea pig biotin-conjugated immunoglobulines (1:200, Chemicon Intl. Inc.; cat. No. AP108B) for the 5- $\mathrm{HT}_{1 \mathrm{~A}}$ receptor; 3) $\mathrm{ABC}$-peroxidase complex: streptavidin-ABC complex/HRP (Dako A/S, Glostrup, Denmark); 4) chromogen: 3,3'DAB (Sigma) $0.2 \mathrm{mg} / \mathrm{mL}$ in $0.2 \mathrm{M}$ Tris $\mathrm{HCl}$ buffer containing $0.03 \%$ hydrogen peroxide. 
Each step was followed by an appropriate wash per triplicate in phosphate-buffer saline. Sections were carefully extended and mounted into gelatine-coated slides, dehydrated, mounted (DPX mountant for histology, Fluka Chemie AG, Buchs, Switzerland), and examined in an Olympus BX50F optic microscope (Olympus Optical Co. Ltd., Japan).

\section{Controls for specificity of the antibodies}

The specificity of the staining obtained in immunohistochemistry experiments was confirmed by preadsorption of the antibodies (anti-GIRK1, anti-GIRK2, anti-GIRK3 and anti-5- $-\mathrm{HT}_{1 \mathrm{~A}}$ receptor) with the addition of an excess of the corresponding control peptide (3:1), which resulted in the complete abolition of immunostaining. The remaining signal was not different from background.

We used a second method to further control the specificity of GIRK1, GIRK2 and GIRK3 antibodies. As described above, western blot experiments were carried out on membrane preparations of cerebral cortex and we corroborated that the autoradiographic signal was abolished when we incubated the antibodies with an excess of the corresponding control peptide (3:1) (see also "Results, Evaluation of GIRK subunit specific antibodies"). We did not use this second method for the 5-HT $1 \mathrm{~A}$ receptor antibody as it was no useful for Western blot analysis.

\section{Analysis of the results}

Cell counting was performed directly at the microscope with the help of Quantimet 500 MC software. For each region, immunolabeled cells present in a predetermined area $\left(32383.2 \mu \mathrm{m}^{2}\right.$, or $2030.5 \mu \mathrm{m}^{2}$ for the habenula) were counted manually in 8 different samples obtained from the 2 hemispheres, out of 2 sections from 2 rats. In the case of the DR 4 different sections from each animal were examined. For a given structure, tissue sections from virtually identical anteroposterior levels were carefully selected for counting. The actual field to count was chosen at random in the first section and the same zone was systematically explored in the following sections. The standard deviations obtained ranged between $5-10 \%$ of the cell counts value. Table 1 contains the results of cell counting as: "++++" very abundant (more than 2500 labeled elements $/ \mathrm{mm}^{2}$ ), “+++" abundant (1500-2500 labeled elements $/ \mathrm{mm}^{2}$ ), “++" moderate expression (1000-1500 labeled elements $/ \mathrm{mm}^{2}$ ), "+" low expression (less than 1000 labeled elements $/ \mathrm{mm}^{2}$ ), "-“ indicates the consistent absence of detectable 
staining and "n.d" indicates that the presence of specific cellular staining could not be determined.

\section{IN SITU HYBRIDIZATION}

\section{Tissue preparation}

Animals were killed by decapitation and the brains rapidly removed, frozen on dry ice and stored at $-20^{\circ} \mathrm{C}$. Tissue sections, $14 \mu \mathrm{m}$ thick, were cut using a microtomecryostat (HM500 OM; Microtom, Walldorf, Germany), thaw-mounted onto APTS (3aminopropyltriethoxysilane; Sigma) coated slides and kept at $-20^{\circ} \mathrm{C}$ until use.

\section{Hybridization probes}

The oligodeoxyribonucleotide probes used were as follows. For the mRNA encoding for GIRK1 channel the five oligonucleotides used were complementary to bases 4-48, 8-31, 137-181, 352-396 and 1504-1548 (GenBank acc. no. U01071). For GIRK2 mRNA four oligonucleotides were used, complementary to bases 219-263, 947991, 1326-1370 and 1401-1446 (GenBank acc. no AB073755). For the mRNA encoding for GIRK3 channel, three oligonucleotides were used, complementary to bases 276-320, 381-425 and 1398-1442 (Gen Bank acc. no L77929). For 5-HT $1 \mathrm{~A}$ receptor mRNA three oligonucleotides were simultaneously used, complementary to bases 1-48, 763-810 and 1219-1266 (Gen Bank acc. no NM_012585).

Glutamatergic cells were identified by the presence of the vesicular glutamate transporters (vGluT) vGluT1 and vGluT2 mRNAs with two oligonucleotides complementary to bases 127-172 and 1756-1800 for vGluT1 (Gen Bank acc. no U07609) and another two oligonucleotides complementary to bases 466-510 and 21562200 for vGluT2 (Gen Bank acc. no AF271235). The distributions of vGluT1 and vGluT2 mRNAs in rat brain show a complementary pattern that agrees with the localization of glutamatergic neurons (Kaneko et al., 2002). GABAergic cells were identified by the presence of the enzyme synthesizing GABA, glutamic acid descarboxylase (GAD), that in adult brain exist as two major isoforms, GAD65 and GAD67 (Soghomonian and Martin, 1998). Immunohistochemical and in situ hybridization histochemistry indicate that the majority of GABA-containing neurons in the brain co-express the genes encoding the two GAD isoforms. Two oligonucleotides for GAD65 isoform were used: bp 159-213 and 514-558 (Gen Bank acc. no 
NM_012563) and another two oligonucleotides were used for GAD67 isoform: bp 191235 and 1600-1653 (Gen Bank acc. no NM_017007). Cholinergic cells were distinguished by the presence of the enzyme choline acetyl-transferase (ChAT) mRNA with two oligonucleotides complementary to bases 880-927 and 1669-1716 of the rat ChAT cDNA sequence (Gen Bank acc. no XM_224626). Since it has been shown that the serotonin transporter is exclusively expressed by serotonergic neurons, we have taken the serotonin transporter (ST) mRNA as indicator of serotonergic phenotype (Fujita et al., 1993). Serotonergic cells were identified by the presence of the serotonin transporter using one oligonucleotide complementary to bases 865-912 (Gen Bank acc. no m79450).

The oligonucleotides were all synthesized and HPLC purified by Isogen Bioscience BV (Maarsden, The Netherlands). Evaluation of the oligonucleotide sequences with basic local alignment search tool of EMBL and Gen-Bank databases indicated that the probes do not show any significant similarity with mRNAs other than their corresponding targets in the rat.

Oligonucleotides for GIRK1, GIRK2, GIRK3 and 5-HT 1 A mRNAs were labeled at their 3 '-end using $\left[\alpha^{-33} \mathrm{P}\right] \mathrm{dATP}(3000 \mathrm{Ci} / \mathrm{mmol}$; New England Nuclear, Boston, MA, USA) for the in situ hybridization histochemistry experiments and terminal deoxynucleotidyltransferase (Oncogene Research Products, San Diego, CA, USA), purified using QIAquick Nucleotide Removal Kit (Qiagen GmbH, Hilden, Germany). For the co-localization studies GIRK, vGluT, GAD, ChAT and ST oligonucleotides (100 pmol) were non-radioactively labeled with the same enzyme and Dig-11-dUTP (Roche Diagnostics $\mathrm{GmbH}$, Mannheim, Germany) according to a previously described procedure (Schmitz et al., 1991).

\section{In situ hybridization histochemistry procedure}

The protocols for single- and double-label in situ hybridization histochemistry were based on a previously described procedure and have been already published (Tomiyama et al., 1997; Landry et al., 2000; Serrats et al., 2003). Briefly, frozen tissue sections were brought to room temperature, fixed for 20 min at $4^{\circ} \mathrm{C}$ in $4 \%$ paraformaldehyde in phosphate-buffered saline (PBS; 1X PBS: 8 mM Na $2 \mathrm{HPO}_{4}, 1.4$ $\mathrm{mM} \mathrm{KH} \mathrm{KO}_{4}, 136 \mathrm{mM} \mathrm{NaCl}, 2.6 \mathrm{mM} \mathrm{KCl}$ ), washed for $5 \mathrm{~min}$ in $3 X$ PBS at room temperature, twice for $5 \mathrm{~min}$ each in $1 \mathrm{X}$ PBS, and incubated for $2 \mathrm{~min}$ at $21^{\circ} \mathrm{C}$ in a solution of predigested pronase (Calbiochem, San Diego, CA, USA) at a final 
concentration of $24 \mathrm{U} / \mathrm{ml}$ in $50 \mathrm{mM}$ Tris- $\mathrm{HCl} \mathrm{pH} 7.5,5 \mathrm{mM}$ EDTA. The enzymatic activity was stopped by immersion for 30 seconds in $2 \mathrm{mg} / \mathrm{ml}$ glycine in $1 \mathrm{X}$ PBS. Tissues were finally rinsed in 1X PBS and dehydrated through a graded series of ethanol. For hybridization, radioactively labeled and non-radioactively labeled probes were diluted in a solution containing 50\% formamide, 4X SSC (1X SSC: $150 \mathrm{mM} \mathrm{NaCl}$, $15 \mathrm{mM}$ sodium citrate), $1 \mathrm{X}$ Denhardt's solution $(0.02 \%$ Ficoll, $0.02 \%$ polyvinylpyrrolidone, $0.02 \%$ bovine serum albumin), 10\% dextran sulfate, $1 \%$ sarkosyl, $20 \mathrm{mM}$ phosphate buffer $\mathrm{pH}$ 7.0, $250 \mu \mathrm{g} / \mathrm{ml}$ yeast tRNA and $500 \mu \mathrm{g} / \mathrm{ml}$ salmon sperm DNA. The final concentrations of radioactive and Dig-labeled probes in the hybridization buffer were in the same range (approximately $1.5 \mathrm{nM}$ ). Tissue sections were covered with hybridization solution containing the labeled probe/s, overlaid with Nescofilm coverslips (Bando Chemical Inc., Kobe, Japan) and incubated overnight at $42^{\circ} \mathrm{C}$ in humid boxes. Sections were washed four times (45 minutes each) in $0.6 \mathrm{M}$ $\mathrm{NaCl}, 10 \mathrm{mM}$ Tris- $\mathrm{HCl} \mathrm{pH} 7.5$ at $60^{\circ} \mathrm{C}$, and once in the same buffer at room temperature for $10 \mathrm{~min}$. For single in situ hybridization experiments, tissue sections were dehydrated in a graduate series of ethanol.

\section{Development of radioactive and non-radioactive hybridization signal}

Hybridized sections were treated as described by (Landry et al., 2000). Briefly, after washing, the slides were immersed for $30 \mathrm{~min}$ in a buffer containing $0.1 \mathrm{M}$ Tris$\mathrm{HCl} \mathrm{pH} \mathrm{7.5,1M} \mathrm{NaCl}, 2 \mathrm{mM} \mathrm{MgCl} 2$ and $0.5 \%$ bovine serum albumin (Sigma) and incubated overnight at $4{ }^{\circ} \mathrm{C}$ in the same solution with alkaline-phosphatase-conjugated anti-digoxigenin-F(ab) fragments (1:5000; Roche Diagnostics $\mathrm{GmbH}$ ). Afterward, they were washed three times (10 min each) in the same buffer (without antibody), and twice in an alcaline buffer containing $0.1 \mathrm{M}$ Tris- $\mathrm{HCl} \mathrm{pH} 9.5,0.1 \mathrm{M} \mathrm{NaCl}$, and $5 \mathrm{mM} \mathrm{MgCl}_{2}$. Alkaline phosphatase activity was developed by incubating the sections with $3.3 \mathrm{mg}$ nitroblue tetrazolium and $1.65 \mathrm{mg}$ bromochloroindolyl phosphate (Roche Diagnostics $\mathrm{GmbH}$ ) diluted in $10 \mathrm{ml}$ of alkaline buffer. The enzymatic reaction was blocked by extensive rinsing in the alkaline buffer containing $1 \mathrm{mM}$ EDTA. The sections were then briefly dipped in 70\% and 100\% ethanol, air-dried and dipped into Ilford K5 nuclear emulsion (Ilford, Mobberly, Chesire, UK) diluted 1:1 with destilled water. They were exposed in the dark at $4{ }^{\circ} \mathrm{C}$ for 5-6 weeks, and finally developed in Kodak D19 (Kodak, Rochester, NY, USA) for 5 min, and fixed in Ilford Hypam fixer (Ilford).

For film autoradiography, some hybridized sections were exposed to Biomax-MR 
(Kodak) films for 4 to 6 days at $-80^{\circ} \mathrm{C}$ with intensifying screens.

\section{Analysis of the results}

The average densities of each mRNA in different brain regions were evaluated semi quantitatively on film autoradiograms with the aid of an image analysis system (MCID M4; Imaging Research, St. Catherines, Ontario, Canada). In table 1 we show these results as: "+++" very strong (relative optical density higher than 0.5 ), "++" moderate (relative optical density from 0.35 to 0.5 ), "+" low (relative optical density lower than 0.35), "-“ indicates that relative optical density was not detected and "n.d" indicates that relative optical density could not be determined.

Tissue sections were examined in bright- and dark-field in a Wild 420 macroscope (Leica, Heerbrugg, Germany) and in a Zeiss Axioplan microscope (Zeiss, Oberkochen, Germany). A Darklite iluminator (Micro Video Instruments, Avon, MA, USA) was used to improve the visualization of autoradioghaphic silver grains and capture of bright and dark-field images.

GIRK and glutamatergic, GABAergic, cholinergic and serotonergic neurons were identified as cellular profiles exhibiting a dark precipitate (alkaline phosphatase reaction product) surrounding or covering the nucleus. GIRK1, GIRK2, GIRK3 and 5-HT1A radioactive-hybridization signal was considered positive when accumulation of silver grains over the stained cellular profiles was at least two- to three-fold higher than the background levels.

Only cellular profiles showing abundance of GIRK1, GIRK2, GIRK3 or 5-HT1A mRNAs and the other GIRK subunits or cell type identifier (vGluT1, vGluT2, GAD, ChAT or ST mRNAs) were considered double labeled.

\section{Controls for specificity of the probes}

The specificity of the autoradiographic signal obtained in the in situ hybridization histochemistry experiments was confirmed by performing a series of routine controls (Pompeiano et al., 1992). For each mRNA under study, at least two different oligonucleotide probes complementary to different regions of the same mRNA were used independently as hybridization probes in consecutive sections of the same animal showing identical hybridization patterns. For a given oligonucleotide probe, addition in the hybridization solution of an excess of the same unlabeled oligonucleotide resulted in the complete abolition of the specific hybridization signal. The remaining 
autoradiographic signal was considered background. The thermal stability of the hybrids was examined by washing at increasing temperatures: a sharp decrease in the hybridization signal was observed at a temperature consistent with the $T_{m}$ of the hybrids (Figure 1).

\section{PREPARATION OF THE FIGURES}

Photomicrography was performed in a Wild macroscope M420 (Leica, Heerbrugg, Switzerland) or a Zeiss Axioplan microscope (Carl Zeiss, Oberkochen, Germany), equipped with a digital camera (DXM1200 F, Nikon) and ACT-1 (Nikon) as image capture software. Figures were prepared for publication using Adobe Photoshop software (Adobe Software, San Jose, CA, USA). Contrast and brightness of images were the only variables we adjusted digitally. 


\section{RESULTS}

\section{Evaluation of GIRK subunit specific antibodies}

As a first approach to determine the levels of expression of GIRK1-3 subunits in rat brain, we characterized the specificity of the immunolabeling of these proteins in cerebral cortical membranes with the antibodies employed. As described previously by Krapivinsky et al.(1995), Liao et al.(1996), Torrecilla et al.(2002), and Koyrakh et al.(2005), GIRK1 immunoreactivity in rat brain cortical membranes was visualized as three bands, the lower molecular weight versions thought to represent core (50 KDa) and core-glycosylated species (55 KDa), and the heavily glycosylated (approximately $60 \mathrm{KDa}$ ) GIRK1 subunit the functional mature protein (Figure 2). Detection of these polypeptides was completely abolished when the antibody was preincubated with excess of synthetic peptide (see Figure 2, A1). These results indicated that the antibody used specifically recognized GIRK1 subunits in rat brain. Analysis of the standard curves revealed a linear relationship between the amount of total membrane protein (1-6 $\mu \mathrm{g})$ in each lane and the relative optical density of the $60 \mathrm{KDa}$ GIRK1 subunits band (see legend Figure 2, A2-A3).

There are four different splice variants of GIRK2 subunits that differ in their sequences mainly at the extreme $\mathrm{N}$ - and C-termini of the subunit (Lesage et al., 1994; Lesage et al., 1995; Isomoto et al., 1996). GIRK2b, which is truncated at the Cterminus and lacks the acidic cluster, shows reduced surface expression. The primary amino acid sequences of GIRK2a and GIRK2c show that these isoforms diverge only at their carboxyl terminal tails. GIRK2c is 11 amino acid residues longer at its Cterminal end than GIRK2a (Lesage et al., 1995). The GIRK2d isoform is predominantly expressed in testis (Inanobe et al., 1999). It has been established that the antibody employed by us recognizes the GIRK2a, $2 c$ and $2 d$ splicing isoforms, but not the ubiquitously expressed GIRK2b splice variant (Lesage et al., 1994; Lesage et al., 1995; Isomoto et al., 1996; Inanobe et al., 1999). Accordingly, our results show that the antibody recognized a band of approximately $75 \mathrm{KDa}$ and a band of lower molecular weight of around $50 \mathrm{KDa}$ in rat cerebral cortex (Figure 2, B1). To demonstrate antibody specificity, GIRK2 antibodies were tested on western blots containing proteins from rat cerebral cortex with blocking peptides. Antibody against the $\mathrm{C}$ terminus of GIRK2 preadsorbed with competitive peptide gave rise to only the $50 \mathrm{KDa}$ immunoreactive 
band (Figure 2, B1). Therefore, the possibility that the $50 \mathrm{KDa}$ immunoreactive band was a deglycosylation product of the $75 \mathrm{KDa}$ was not considered further. Potentially, both GIRK2a and GIRK2c splice variants could contribute to the $75 \mathrm{KDa}$ immunoreactive band. Analysis of the standard curves revealed a linear relationship between the amount of total membrane protein $(2.5-20 \mu \mathrm{g})$ in each lane and the relative optical density of the 75 KDa GIRK2 subunits band (see legend Figure 2, B2-B3).

Figure 2, C shows representative immunoblots of GIRK3 subunits in crude plasmatic membranes from rat brain cortex. One band migrating at expected molecular mass (approximately $40 \mathrm{KDa}$ ) is shown. To demonstrate antibody specificity, GIRK3 antibodies preincubated with blocking peptides were tested on western blots containing proteins from rat cerebral cortex. Antibody against the C-terminal domain of GIRK3 subunit preadsorbed with competitive peptide gave rise to no immunoreactive bands (Figure 2, C1). Analysis of the standard curves revealed a linear relationship between the amount of total membrane protein (5-40 $\mu \mathrm{g})$ in each lane and the relative optical density of the GIRK3 subunits band (see legend Figure 2, C2-C3).

\section{GIRK and 5- $\mathrm{HT}_{1 \mathrm{~A}}$ receptor protein and $\mathrm{mRNA}$ distribution in rat brain}

Immunocytochemistry studies carried out with specific polyclonal antibodies against GIRK1, GIRK2 and GIRK3 subunits and the $5-\mathrm{HT}_{1 \mathrm{~A}}$ serotonin receptor at various coronal levels from adult rat brain confirmed that all GIRK subunits analyzed are very abundant in the rat forebrain and that the $5-\mathrm{HT}_{1 \mathrm{~A}}$ receptor is present notably in certain areas. Moreover, in situ hybridization studies also showed that the mRNAs corresponding to these GIRK channel subunits are widely and heterogeneously distributed along the rat brain. Analysis of emulsion-dipped coronal brain sections revealed more details of the hybridization pattern at the cellular level. In all cases, we observed some nuclei with a strong hybridization signal in contrast to some other regions with no detectable signal. The distribution pattern of the three GIRK subunits studied was very similar. However, some differences between the brain expressions of these GIRK subunits can be pointed out.

GIRK1 subunit. Results are summarized in Table 1 and illustrated in Figure 3, A1-G1. In the particular case of the GIRK1, we found a high density of stained cells through all cortical layers with higher density in layer VI. This protein was also found as a stained neuropil in layer IV and in apical dendrites through the different layers. The 
mRNA encoding GIRK1 was also widely distributed through all cortical layers although the highest density of this mRNA expression appeared in layer IV (Figure 4, A1-A2). The piriform cortex was the cortical area where both GIRK1-immunoreactive (IR) cells and its mRNA were expressed at highest densities. The dentate gyrus and the pyramidal layer of the hippocampus were among the most prominently labeled brain regions when stained with specific antibodies and also when hybridized with GIRK1 33P-labeled probes (Figure 5, A1-A2). In the septum the number of cells showing GIRK1-IR seamed to be higher than the density of mRNA positive cells that was noticed in this area. Similarly, in the caudate-putamen, abundant small cells containing GIRK1-immunoreactivity (IR) were found, although the staining was quite weak. In contrast, the hybridization signal in this area was very low. It was notable the presence of GIRK1-IR in the medial and lateral habenular nuclei with the highest number of immunostained cells per $\mathrm{mm}^{2}$ in the medial nucleus. The presence of GIRK1 mRNA was moderate in the medial habenular nucleus and lower in the lateral nucleus (Figure 6, A1-A3). In the thalamus high number of cells showed GIRK1-IR and also, moderate hybridization signal was observed with the in situ hybridization experiments (Fig. 7, A1A3). Interestingly, the arcuate, the paraventricular and the supraoptic nuclei (Figure 8) showed a high number of immunostained cells, although a very low hybridization signal could be detected in these three nuclei of the hypothalamus. In other hypothalamic nuclei, the number of GIRK1-IR cells was abundant in contrast to a low presence of mRNA at this level. In the red nucleus it was possible to observe large stained cells although they were not abundant. Moderate GIRK1-IR was found in the ventral tegmental area as well as in the compact part of the substantia nigra. However, no mRNA expression could be detected in these two areas. With regard to the dorsal raphe nucleus, abundant GIRK1-IR cells were found although low densities of mRNA were observed in this nucleus. In the pontine nucleus, we observed numerous GIRK1IR cells and moderate densities of mRNA expression. In the locus coeruleus, we found a low presence of GIRK1 mRNA. In contrast, in the granular cell layer of the cerebellum abundant GIRK1-IR cells and a very strong hybridization signal were found. In the cerebellum we found GIRK1 mRNA expressing-cells in the granular layer and there was an absence of mRNA expression in Punkinje cells (Figure 9, A1-A3).

In relation to the subcellular localization, GIRK1-IR was found in cell bodies of immunostained neural cells and dendrites, for example in apical and basal dendrites of the pyramidal layer of the hippocampus as well as in granule cells of the dentate gyrus 
(Figure 6, A2) and also in the apical dendrites of cells in the cerebral cortex. GIRK1-IR fibers were also present in the lateral septum (data not shown).

GIRK2 subunit. GIRK2 protein and its mRNA also presented a widespread distribution in the rat brain, as summarized in Table 1 and illustrated in Figure 3, A2-G2. All different neocortical areas examined presented a high density of GIRK2immunostained cells through all layers. Nevertheless, because of the characteristics of the staining in the cortex, it was not possible to count neuronal cell bodies in every cortical layer. The most important characteristic of GIRK2-IR in layers II to III was the presence of stained fibers oriented perpendicularly to the surface of the cortex with an intense neuropil in layer I. GIRK2-IR cells were found, in particular, in pyramidal cell bodies of layer V. GIRK2 mRNA was also observed through all cortical layers (Figure 4, B1-B2). As in the case of GIRK1 subunit, GIRK2-IR and its mRNA were both enriched in piriform cortex. In the hippocampal formation, a large number of GIRK2-IR cell bodies were found in the pyramidal layer of all CA subfields and in the granule cell layer of the dentate gyrus, surrounded by an intensely stained neuropil. This abundant expression of GIRK2-IR in the hippocampus was paralleled by a very strong hybridization signal obtained for the corresponding mRNA (Figure 5, B1-B2). Similarly to more superficial layers of the cortex, the number of GIRK2-IR cells in the septum could not be determined because of the presence of abundant stained fibers. However, by in situ hybridization, we demonstrated a moderate presence of GIRK2 mRNA in the septum. In the caudate-putamen, neither GIRK2-IR nor its mRNA showed a significant signal. In the habenula, high numbers of GIRK2-IR cells and strong signal of GIRK2 mRNA were observed in the medial nucleus. These densities were lower in the lateral habenula which was characterized by the presence of abundant IR-fibers and varicosities (Figure 6, B1-B3). In the thalamus numerous cells expressed GIRK2-IR and showed a moderate hybridization signal (Figure 7, B1-B3). We observed a remarkable presence of GIRK2-IR in the arcuate, the paraventricular and the supraoptic nuclei of the hypothalamus, where large neurons were intensely immunostained. These results correlated with a moderate to very strong hybridization signal. In the rest of the hypothalamic nuclei, GIRK2 mRNA was relatively abundant, although no GIRK2-IR could be detected. Very few large GIRK2-stained cells were observed in the red nucleus (Figure 10). Other areas enriched in GIRK2-IR were the ventral tegmental area, with an important presence of immunostained fibers, and the substantia nigra. In the latter, and specifically in its compact part, the staining of neural cell bodies was very 
intense and fibers penetrating into the reticular part were the most important characteristics, together with positively stained dendritic spines (Figure 11). In the dorsal raphe nucleus a few IR-cells were found, and we could determine a moderate intensity in GIRK2 mRNA expression signal. Abundant cells were GIRK2-IR in the pontine nucleus, with a moderate density of mRNA. In the locus coeruleus, intermediate levels of GIRK2 mRNA were found. Intense GIRK2-IR and hybridization signal was found in the granule cell layer of the cerebellum. A high GIRK2 mRNA labeling was also seen in the Punkinje cells (Figure 9, B1-B3).

In general, GIRK2 protein was found at a somatodendritic level, for example in the hippocampus, and we also found IR-fibers in the cortex, the lateral habenular nucleus and the reticular part of the substantia nigra.

GIRK3 subunit. This subunit also showed a wide distribution in the rat brain (Table 1 and Figure 3, A3-G3). GIRK3 was expressed in all cortical layers with higher number of IR-cells per $\mathrm{mm}^{2}$ in the most superficial layers (II and III). The distribution of GIRK3 mRNA was in agreement with the IR-expression pattern in the different cortical layers with a high presence of mRNA in layers II-III and a little bit stronger density of mRNA in layer IV (Figure 4, C1-C2). Both GIRK3-IR and its mRNA were most abundant in the piriform cortex. In the dentate gyrus and the pyramidal layer of the hippocampus we found a high number of positive immunostained cells. Both structures exhibited only moderate densities of GIRK3 mRNA (Figure 5, C1-C2). A dense plexus of immunostained fibers was found in the septum. It was not possible to determine the density of GIRK3 IR-cells due to the presence of numerous immunostained fibers in this area. Using in situ hybridization, we demonstrated a very low presence of this mRNA in the septum. In the caudate-putamen a moderate number of cells were GIRK3-IR. The hybridization signal in this area was very low. It was notable the GIRK3IR in the habenula, mainly in its medial part. In contrast, the presence of the corresponding mRNA was very low in both parts of the habenula (Figure 6, C1-C3). In the thalamic nuclei GIRK3-IR and mRNA were expressed at moderate levels (Figure 7, C1-C3). GIRK3-IR was found abundantly in cells of the paraventricular and the supraoptic nuclei of the hypothalamus with a distinct and intense staining, although the hybridization signal was not detected in the supraoptic nucleus and was very low in the paraventricular nucleus. Interestingly, GIRK3-IR was abundant in many hypothalamic nuclei but a low presence of hybridization signal was noticed. GIRK3-IR could also be seen in large stained cells in the red nucleus. The staining pattern of GIRK3-IR in the 
ventral tegmental area as well as in the reticular part of the substantia nigra was its presence in fibers which did not allow the visualization of stained cell bodies. In the compact part of the substantia nigra, a few neural cells showed GIRK3-IR. In none of these areas the corresponding mRNA could be detected. Regarding the dorsal raphe nucleus, a moderate number of cells positively immunostained for this protein were found and a low density of hybridization signal was observed. Few GIRK3-IR cells and low mRNA densities were observed in the pontine nucleus. In the locus coeruleus, low amounts of GIRK mRNA were detected. Abundant GIRK3-IR cells were found in the granule cell layer of the cerebellum, which showed also a strong hybridization signal. GIRK3 mRNA labeling was also seen in Punkinje cells (Figure 9, C1-C3).

In relation to its subcellular localization, GIRK3-IR was mainly present in cell bodies of neural cells, dendrites and axon-like fibers.

$5-\mathrm{HT}_{1 \mathrm{~A}}$ receptor. The expression of this serotonin receptor along the rat brain has some similarities with the localization of the studied GIRK subunits (Figure 3, A4G4). We found $5-\mathrm{HT}_{1 \mathrm{~A}}-\mathrm{IR}$ in all cortical layers; especially in the most internal ones (layers $\mathrm{V}$ and $\mathrm{VI}$ ). The density of the hybridization signal was low in all neocortical areas and the highest intensities corresponded to the internal layers (layers $\mathrm{V}$ and $\mathrm{VI}$ ). The hippocampal formation exhibited very high densities of $5-\mathrm{HT}_{1 \mathrm{~A}}-\mathrm{IR}$ cells and $5-\mathrm{HT}_{1 \mathrm{~A}}$ mRNA labeling (Figure 3, D4-E4 and Figure 5, D1-D2). Abundant stained fibers were seen in the septum together with $5-\mathrm{HT}_{1 \mathrm{~A}}-\mathrm{IR}$ cell bodies. These cells showed a moderate density of mRNA. It was notable the presence of $5-\mathrm{HT}_{1 \mathrm{~A}}-\mathrm{IR}$ in the medial habenular nucleus, however, its corresponding mRNA was not detected. In the thalamus the expression of both the protein and its mRNA were quite low. We could emphasize the presence of remarkable levels of mRNA encoding this receptor in the zona incerta (Figure 3, C4). There were abundant 5- $\mathrm{HT}_{1 \mathrm{~A}}-\mathrm{IR}$ cells in the arcuate, paraventricular and supraoptic nuclei. Nevertheless, no mRNA could be detected in none of these three areas. In the other hypothalamic nuclei, $5-\mathrm{HT}_{1 \mathrm{~A}}-\mathrm{IR}$ and its mRNA expression were very low. In the case of the red nucleus there were a low number of intensely stained cells. In the substantia nigra a low expression of the $5-\mathrm{HT}_{1 \mathrm{~A}}-\mathrm{IR}$ was found in the compact part but no mRNA was detected in the entire area. In contrast, abundant $5-\mathrm{HT}_{1 \mathrm{~A}}$ receptor-IR cells were found in the dorsal raphe nucleus which showed also very high densities of mRNA (Figure 3, F4). The expression of this receptor in the pontine nucleus was moderate and we noticed a low presence of mRNA. In the locus coeruleus, it was noticed a moderate signal of mRNA. 
The 5- $\mathrm{HT}_{1 \mathrm{~A}}$ receptor appeared expressed in cell bodies and dendrites of neural cells, for example in the medial septum.

\section{Co-localization of GIRK subunits}

In order to analyze the cellular coexistence of the different GIRK mRNAs, we performed double in situ hybridization experiments using ${ }^{33} \mathrm{P}$-labeled and Dig-labeled probes to detect the GIRK subunits. The co-localization of GIRK subunits was examined in dentate gyrus, pyramidal layer of the hippocampus, cortex and thalamic nuclei (Figure 12).

As shown in Figure $12(\mathrm{~A})$, in the dentate gyrus of the hippocampus GIRK1 mRNA hybridization signal can be clearly seen as autoradiographic grains over GIRK2 mRNA-expressing cell profiles. Within this area, the vast majority of the cells were both GIRK1 and GIRK2 mRNA-positive, although we could also see a few GIRK1 or GIRK2 single-labeled cells. Similarly, in Figure 12 (B) GIRK3 mRNA and GIRK1 mRNA as well as GIRK3 and GIRK2 mRNAs (Figure 12, C), co localized in a large number of cells along the dentate gyrus.

In the pyramidal layer of the hippocampus, the large majority of cells also showed double-hybridization signal of GIRK1 and GIRK2, GIRK1 and GIRK3 and GIRK2 and GIRK3 mRNAs with only few single-labeled cells (Figure 12, D-F).

A high percentage of cells in the cerebral cortex (Figure 12, G-I) and the thalamus (Figure 12, J-L) showed co expression of the pairs of GIRK subunits analyzed, but considerable numbers of single-labeled cells were also found.

\section{GIRK subunits in glutamatergic cells}

Glutamatergic cells were identified by the presence of the vesicular glutamate transporters vGluT1 and vGluT2 mRNAs and were detected simultaneously in tissue sections using non-radioactive probes. The presence of the GIRK subunit mRNAs was determined using ${ }^{33} \mathrm{P}$-labeled oligonucleotides.

In the dentate gyrus (Figure 13, A1-A3) and pyramidal cell layer of the hippocampus (Figure 13, B1-B3), the vast majority of the glutamatergic cells were GIRK mRNA-positive. Only a few vGluT mRNA containing cells lacked GIRK mRNA and a few cells expressing mRNA coding one of the GIRK proteins were not 
glutamatergic.

In the cerebral cortex, the vast majority of glutamatergic cells also co-expressed GIRK subunits. In contrast to the hippocampus, many GIRK mRNA-positive cells were devoid of vGluT mRNA (Figure 13, C1-C3).

In the thalamus, the majority of labeled cells were double-positive and showed mRNA encoding vGluT and one of the GIRK subunits, but substantial populations of GIRK-negative glutamatergic cells as well as GIRK-positive non-glutamatergic cells were observed (Figure 13, D1-D3).

\section{GIRK subunits in GABAergic cells}

GABAergic cells were identified by the presence of the glutamic acid descarboxylase (GAD65 and GAD67) mRNAs and were detected in tissue sections using non-radioactive probes. The presence of the GIRK subunit mRNAs was determined using ${ }^{33} \mathrm{P}$-labeled oligonucleotides.

The majority of GIRK mRNA-expressing cells in the dentate gyrus (Figure 14, A1-A3), the pyramidal cell layer of the hippocampus (Figure 14, B1-B3) and the cerebral cortex (Figure 14, C1-C3), did not show GAD mRNA signal. In these structures, most of GABAergic cells were also GIRK mRNA-positive.

Virtually all cells in the thalamus showing GIRK mRNAs were devoid of GAD mRNA. In contrast, in the reticular thalamic nucleus, GIRK mRNAs were always found in GAD mRNA-containing cells. Some GAD mRNA-positive cells that lacked GIRK mRNA were also found in the reticular thalamic nucleus (Figure 14, D1-D3).

\section{GIRK subunits in cholinergic cells}

Cholinergic cells were distinguished by the presence of choline acetyltransferase (ChAT) mRNA. We detected these cells in the nucleus of the vertical limb of the diagonal band using non-radioactive probes. The presence of the GIRK subunit mRNAs was determined using ${ }^{33} \mathrm{P}$-labeled oligonucleotides. The majority of cholinergic cells expressed GIRK1 or GIRK2 mRNA. Some GIRK1 mRNA- and some GIRK2 mRNA-positive cells devoid of ChAT mRNA were also observed (Figure 15, A-H). GIRK3 mRNA expression was absent in this area. 


\section{Co-localization of GIRK subunit mRNAs and 5-HT $1 A$ receptor mRNA}

We analyzed the cellular co-existence of the $5-\mathrm{HT}_{1 \mathrm{~A}}$ receptor mRNA and GIRK subunits through double in situ hybridization. We used ${ }^{33} \mathrm{P}$-labeled oligonucleotides for the serotonin receptor and Dig-labeled probes to detect GIRK subunits. The colocalization of these three GIRK subunits with the $5-\mathrm{HT}_{1 \mathrm{~A}}$ receptor was examined in dentate gyrus, pyramidal layer of the hippocampus, cortex, septum and dorsal raphe.

In the dentate gyrus (Figure 16, A1-A3) and pyramidal layer of the hippocampus (Figure 16, B1-B3) as well as in the cerebral cortex (Figure 16, C1-C3), the vast majority of $5-\mathrm{HT}_{1 \mathrm{~A}}$ receptor-expressing cells showed GIRK subunit mRNAs. Cells that expressed GIRK mRNA and were 5- $\mathrm{HT}_{1 A}$ mRNA-negative, were also observed in the dentate gyrus and CA fields of the hippocampus. This type of cells was very abundant in the cerebral cortex.

In contrast, in the septum, GIRK mRNA was mostly found in 5- $\mathrm{HT}_{1 \mathrm{~A}}$ receptor mRNA-expressing cells. Nevertheless, numerous $5-\mathrm{HT}_{1 \mathrm{~A}}$ receptor mRNA positive cells lacked GIRK mRNA labeling (Figure 16, D1-D3).

In the dorsal raphe nucleus, the majority of cells expressing the serotonin receptor 5- $\mathrm{HT}_{1 \mathrm{~A}}$ mRNA were also GIRK mRNA-positive. Few cells were found that expressed GIRK mRNAs without co-expression of 5-HT 1 A receptor mRNA (Figure 16, E1-E3). In general, the expression of GIRK3 mRNA in the dorsal raphe nucleus was more limited than GIRK1 and GIRK2 in terms of number of labeled cells.

\section{GIRK subunits in serotonergic cells}

Serotonergic cells were identified by the presence of the serotonin transporter (ST) mRNA in the dorsal raphe nucleus. We used ${ }^{33} \mathrm{P}$-labeled oligonucleotides to detect the ST mRNA and Dig-labeled probes for GIRK subunits. In most of the cells expressing the ST mRNA we also found GIRK mRNA. In addition, only a few cells were found that expressed GIRK mRNA without apparent ST mRNA labeling (Figure 17). 


\section{DISCUSSION}

In this work we have carried out a comparative analysis of the distribution of the GIRK1, GIRK2, GIRK3 subunits and 5- $\mathrm{HT}_{1 \mathrm{~A}}$ receptor in the rat brain. Our study is the first to compare the expression of these proteins and their corresponding mRNAs in different brain areas. In addition, we have examined the co-expression of the mRNAs codifying the GIRK subunits and their presence in glutamatergic, GABAergic, cholinergic, serotonergic and $5-\mathrm{HT}_{1 \mathrm{~A}}$ receptor-containing cells in selected rat brain structures. Moreover, to our knowledge, this is the first detailed report of the distribution of the GIRK3 protein in the adult rat brain.

\section{GIRK1, GIRK2 and GIRK3 protein and mRNA expression}

GIRK1 protein-immunoreactivity (IR) showed a wide distribution along the different brain areas analyzed. It is noteworthy its presence in areas such as the cerebral cortex, hippocampal formation, habenular nuclei, thalamic nuclei, some hypothalamic nuclei and the granular layer of the cerebellum. Studies by Bausch et al. (1995) showed a similar distribution of GIRK1, although this group observed this protein in dendrites of granular and pyramidal cells of the hippocampus, while they did not recognize clearly its presence in the somata of these neurons. In contrast, Ponce et al. (1996), Miyashita and Kubo (1997) and us found immunoreactivity in the somata and dendrites of pyramidal cells in the CA1-3 as well as in the granular layer of the dentate gyrus. In fact, the high presence of GIRK1 protein in dendrites and also in cell bodies of the pyramidal layer of the hippocampus has already been described by Drake et al. (1997). Liao et al. (1996) found GIRK1 in the pyramidal cells but not in the granule cells of the dentate gyrus. These discrepancies could be due to technical differences, such as the use of different antibodies with different specificity. In the cerebral cortex, the neuropil was GIRK1-positive as already reported by Liao et al. (1996), Ponce et al. (1996) and Miyashita and Kubo (1997). Apparently, the labeling was stronger in layer IV, which contains thalamocortical projections that, most likely, contribute to the immunostaining in the cortex. This has been demonstrated by Ponce et al. (1996) using unilateral kainate lesions of the thalamus that resulted in a loss of staining on the side ipsilateral to the lesion in cortical layer IV. In addition, some studies have analyzed the localization of mRNA through in situ hybridization in the rat brain 
and also in the mouse brain (Karschin et al., 1994; DePaoli et al., 1994; Kobayashi et al., 1995; Karschin et al., 1996). In agreement with these authors, we found a very high density of GIRK1 mRNA in the cerebral cortex, hippocampus (dentate gyrus and CA1, CA2 and CA3 fields of hippocampus), thalamic nuclei and the cerebellar granular layer.

The distributions of GIRK1-IR and its mRNA are coincident in the cerebral cortex, hippocampus, amygdala, thalamic nuclei, pontine nuclei and granular layer of the cerebellum. In contrast, this parallelism is not so evident in other structures such as the septum, caudate putamen, habenular nuclei, hypothalamic arcuate, paraventricular and supraoptic nuclei, and substantia nigra, where an important number of cells were immunoreactive but expressed only low mRNA densities.

Our distribution of GIRK2 protein-IR is in accordance with a previous work by Murer et al. (1997), who noticed an intense immunostaining of cell bodies in the septum, hippocampus, compact part of the substantia nigra and granular layer of the cerebellum. We found strongly GIRK2-IR fibres in areas such as the external layers of the cerebral cortex (with stained fibres oriented perpendicularly to the surface of the cortex), septum, lateral habenular nucleus and reticular part of the substantia nigra with remarkably stained dendrites, fibres and spines. This distribution is comparable to that described by Murer et al. (1997) and Liao et al. (1996). In addition, we found a strong staining of GIRK2 protein in the arcuate and the paraventricular nuclei of the hypothalamus, which has not been described before. In contrast to these authors, we found positively stained cells in the red nucleus and the dorsal raphe. As in the case of the GIRK1 subunit, the use of different antibodies can be the reason of these differences between studies. In the present study, the specificity of the immunostaning was assessed by preadsorption of the antisera with the corresponding control peptide antigens.

The distribution of the mRNA encoding GIRK2 protein in the adult rat brain we described in this work is in agreement with previously published localizations in the mouse and rat brain (Kobayashi et al., 1995; Liao et al., 1996). GIRK2 mRNA was substantially expressed in the hippocampus, ventral tegmental area, substantia nigra and the granular layer of the cerebellum. A moderate expression of this subunit was observed in the cerebral cortex, thalamic and hypothalamic nuclei, supraoptic nucleus, pontine nuclei and dorsal raphe nucleus and a lower signal was noticed in the caudate putamen and septum. In general, there was a good correlation between the GIRK2 protein expression and the localization of its corresponding mRNA. It is noteworthy that 
in areas such as the superficial layers of the cerebral cortex and the septum, where we described stained fibres and were not able to detect cellular immunostaining, we did find mRNA hybridization signal.

With regard to the GIRK3 subunit, to our knowledge, this is the first study on the distribution of this protein in the adult rat brain apart from the study carried out by Grosse et al. (2003) based on GIRK3-IR in the hippocampus. It is remarkable, the presence of GIRK3-IR in layers II-III of the cerebral cortex, hippocampus, amygdala, medial habenular nucleus, some hypothalamic nuclei such as the paraventricular and supraoptic nuclei and also in the granular layer of the cerebellum. We found this protein not only in cell bodies but also in fibres of the septum, ventral tegmental area and substantia nigra. Using in situ technique, we also found high densities of mRNA encoding the GIRK3 subunit in the cerebral cortex, hippocampal formation, amygdala, thalamic nuclei, posterior hypothalamic nuclei and cerebelum. These results are in accordance with those described by Karschin et al. (1996). However, these authors found mRNA-positive cells in the nucleus of the vertical limb of the diagonal band, caudate putamen and globus pallidus, where we noticed only very low hybridization signal. These results show that this GIRK3 subunit is located in areas where GIRK1 and GIRK2 are also expressed and this parallelism is in agreement with the possible formation of heterotetrameric GIRK channels GIRK1/3 and GIRK2/3 as well as homomeric GIRK3 channels.

It is important to highlight that, in general, the anatomical distributions of cell bodies immunoreactive for the three different GIRK subunits are highly comparable to their respective mRNAs, indicating that these proteins are mainly expressed at the somatodendritic level. This subcellular localization is coherent with their function as $G$ protein-regulated channels. However, we also observed some cases of mismatch between mRNA and GIRK-IR. For example, we found relatively strong GIRK1- and GIRK3-IR in the supraoptic nucleus, where mRNA levels were very low.

In synthesis, we report that the three GIRK subunits are widely distributed along the adult rat brain and present similar anatomic localizations (see Table 1). In particular, they have overlapping distributions in the cerebral cortex, hippocampus, thalamic nuclei, paraventricular and supraoptic nuclei, pontine nuclei and the granular layer of the cerebellum among others. However, this is not the case in other areas, for example, the GIRK1 subunit is found in the caudate putamen where the other GIRK subunits are only moderately expressed. In this area, we could expect to find more 
GIRK1/2 and GIRK1/3 than any other combination of subunits. It is noteworthy the presence of GIRK2 subunit in the substantia nigra where there are a vast majority of homotetrameric GIRK channels composed by four GIRK2 subunits in dopaminergic cells or the GIRK3 subunit in the amygdala (Inanobe et al., 1999).

\section{GIRK mRNAs co-expression}

We used double in situ hybridization to analyze the cellular co-expression of different GIRK subunits in brain areas with a high degree of co-localization, such as the dentate gyrus, pyramidal layer of the hippocampus, cortex and thalamic nuclei. Independently of the two GIRK subunits selected, we found a similar pattern of coexpression. For example, we found numerous cells expressing GIRK1 and GIRK2 mRNA subunits, along with a few GIRK1 mRNA positive cells and a few GIRK2 mRNA positive cells. These single labeled cells are likely to contain GIRK1/3 channels and GIRK2/2 or GIRK2/3 channels, respectively. In summary, we demonstrated the coexistence of different subunits in variable combinations in rat brain, suggesting that different subunit organizations of the GIRK channels might occur in different neurons, resulting in diversity of channel functions.

\section{GIRK mRNAs expression in glutamatergic, GABAergic and cholinergic cells}

Another important aim of our study was to determine whether these GIRK channels are present in glutamatergic, GABAergic and cholinergic cells. Our work provides evidence showing that the vast majority of glutamatergic and GABAergic cells in the dentate gyrus, pyramidal layer of the hippocampus and the cerebral cortex, express GIRK mRNAs. In the thalamus, however, we found GIRK subunits in a high proportion of glutamatergic cells, but not in GABAergic neurons, with the exception of the reticular thalamic nucleus, where GIRK mRNAs always co-localized with GAD mRNA. Almost all cholinergic cells studied in the nucleus of the vertical limb of the diagonal band showed GIRK1 or GIRK2 mRNA labeling, whereas no GIRK3 mRNA was found. Therefore, GIRK channels in this area are likely to contain GIRK1 and GIRK2 subunits. 


\section{5-HT $1 \mathrm{~A}$ receptor distribution and co-localization with GIRK subunits. GIRK mRNAs expression in serotonergic cells of the dorsal raphe nucleus}

Similarly to cholinergic cells, we found expression of GIRK subunits in serotonergic cells of the raphe nuclei as identified by the presence of serotonin transporter mRNA. This suggests that GIRK channels are able to mediate inhibitory responses in this area and regulate serotonin release from the raphe nuclei to the hippocampus, septum and other projection areas. Consequently, these channels could have an important role in learning and memory.

On the other hand, it has been long know that the activation of GPCR coupled to Gi/o proteins can cause the opening of GIRK channels through a membrane-delimited pathway. It has already been proved that, in mammalian neurons and in Xenopus oocytes, GIRK channels can be activated by neurotransmitters through GPCR such as the serotonin $5-H T_{1 A}$, muscarinic $M_{2}$, dopamine $D_{2}, D_{3}$ and $D_{4}, \alpha_{2}$-adrenergic, metabotropic mGluR1a, 2 and 7, $\mathrm{GABA}_{\mathrm{B}}$, neuropeptide $\mathrm{Y} 1$ and $\mathrm{Y} 2$, cannabinoid, melatonin, adenosine $A_{1}, \mu-, \delta$ - and $\mathrm{K}$-opioid and nociceptin/orphanin receptors (Andrade et al., 1986; North, 1989; Brown and Birnbaumer, 1990; Hille, 1992; Lesage et al., 1995; Kim et al., 1995; Murer et al., 1997; Karschin, 1999). Moreover, GIRK subunit knock-out mice have revealed important roles for GIRK channels in the generation of IPSPs in hippocampal and cerebellar neurons, where they serve as a common effector for various neurotransmitters. For instance, in hippocampal neurons of GIRK2 knock-out mice there is an evident loss of responsiveness both to $5-\mathrm{HT}_{1 \mathrm{~A}}$ and $\mathrm{GABA}_{B}$ agonists (Luscher et al., 1997; Slesinger et al., 1997). Therefore, since GIRK channels could be acting as important effectors of $5-\mathrm{HT}_{1 \mathrm{~A}}$ receptors upon activation by serotonin or serotonin agonists, we carried out co-localization assays in the adult rat brain, in order to determine whether GIRK subunits are expressed in 5-HT 1 A positive cells and could thus mediate regulatory responses through this receptor. The distribution pattern of the 5- $\mathrm{HT}_{1 \mathrm{~A}}$ receptor and its mRNA reported here is in accordance with previous data from Kia et al. (1996) and Chalmers and Watson (1991) and Pompeiano et al. (1992), respectively. In general, there is a good concordance between $5-\mathrm{HT}_{1 \mathrm{~A}}$ protein distribution and the expression of its mRNA, both showing the highest densities in the hippocampus, cerebral cortex, septum and raphe nuclei. It is worth mentioning that clear mismatches are found in nuclei such as the habenula as well as in the hypothalamic supraoptic, paraventricular and arcuate nuclei, where we 
and other authors (Collin et al., 2002) find 5- $\mathrm{HT}_{1 \mathrm{~A}}$ receptor immunoreactive neurons but the corresponding mRNA is not detected (see also Chalmers and Watson 1991). These mismatches might be due to particular turnover rates of $5-\mathrm{HT}_{1 \mathrm{~A}}$ receptor protein and/or mRNA in these regions compared to other brain areas, which might result in undetectable levels of this mRNA. We found GIRK subunits co-expressed with both somatodendritic $5-\mathrm{HT}_{1 \mathrm{~A}}$ autoreceptors in the raphe nuclei and with postsynaptic 5- $\mathrm{HT}_{1 \mathrm{~A}}$ heteroreceptors in projection areas. Our results suggest that GIRK channels can mediate inhibitory responses in these areas when serotonin or its agonists activate the serotonin receptor $5-\mathrm{HT}_{1 \mathrm{~A}}$.

In summary, this work provides for the first time a useful and until now unknown evidence showing that most glutamatergic, GABAergic, cholinergic and serotonergic cells in the rat brain areas studied show mRNA codifying the GIRK channels forming subunits GIRK1, 2 and 3. Therefore, these channels can be found expressed in the plasmatic membrane of these cells controlling the release of both excitatory and inhibitory neurotransmitters to their projection areas and so, they could play a very important role in the regulation of neuronal excitability of different neurons in a variety of brain regions. Moreover, the close relationship between $5-\mathrm{HT}_{1 \mathrm{~A}}$ receptor $\mathrm{mRNA}$ and GIRK1-3 channel mRNAs on both GABAergic and glutamatergic neurons of the rat hippocampus, provides an anatomical framework to explain the important role as modulator of hippocampal functions, such as learning/memory and emotional state, of serotonin via 5-HT $1 \mathrm{~A}$ receptors using as effectors the GIRK channels coupled to this receptor trough the heterotrimeric $G_{i / o}$ proteins. This may have important clinical implications in aging, dementia and affective disorders.

On the one hand, since there is a high colocalizacion between GIRK subunits and the serotonin receptor, and also with the serotonin transporter (marker of serotonergic neurons) in the dorsal raphe nucleus, we may think that substances that could specifically inhibit these channels in this brain area would be useful in controlling the depressive illness. In fact, with current antidepressant treatments, such as selective serotonin reuptake inhibitors, we look for an increase in the neurotransmitter serotonin levels in areas such as the hippocampus. By inhibiting the activity of these GIRK channels, we could induce a greater depolarization of serotonergic neurons at the raphe nucleus and therefore, achieve higher levels of this neurotransmitter in projection areas. 
On the other hand, the fact that these GIRK channels are expressed in a wide variety of brain structures is indicative of their importance as effectors of many different receptors and therefore, their pharmacological control can be a great benefit to the treatment of a wide range of pathologies such as anxiety disorders, prevention of damage in situations of ischemia, treatment of drug addiction, and so forth, as has been pointed out by other authors before (Blednov et al., 2001; Mao et al., 2002; Morgan et al., 2003; Kobayashi et al., 2006).

Therefore, a greater knowledge of the brain location of the GIRK subunits presented in this paper may present a starting point for considering these channels as future therapeutic targets in the control of various pathologies as well as to understand some of the adverse effects caused by drugs currently used in therapeutic such as some antidepressants that acting on GIRK channels at heart can cause bradycardy in overdose (Kobayashi et al., 2003; Kobayashi et al., 2004).

\section{ACKNOWLEDGEMENTS}

We would like to thank Rocío Martín, Silvia Serrano and Juan Manuel Rodríguez for their technical assistance. 


\section{FIGURE LEGENDS}

Figure 1.- A-C: Specificity control of the hybridization signal with the GIRK1-1 (137181) oligonucleotide probe. Rat coronal consecutive sections were hybridized with the ${ }^{33}$ P-labeled GIRK1-1 probe. Hybridized sections were washed at increasing temperatures of $60^{\circ} \mathrm{C}(\mathrm{A}), 70^{\circ} \mathrm{C}(\mathrm{B})$ and $80^{\circ} \mathrm{C}(\mathbf{C})$. A large decrease in the hybridization signal could be observed at $80^{\circ} \mathrm{C}$. Black spots in $\mathrm{C}$ are non specific staining. D-F: Cohybridization experiments. The signal obtained with the GIRK1-1 labeled oligonucleotide (A) was completely blocked by competition with a 50 -fold excess of the corresponding unlabeled probe (D). The same hybridization pattern as with the GIRK11 probe was observed with the ${ }^{33} \mathrm{P}$-labeled GIRK1-2 (352-396) oligonucleotide probe (E). The signal obtained with the GIRK1-2 labeled oligonucleotide (E) was completely pageed by competition with a 50 -fold excess of the corresponding unlabeled probe (F). Pictures are digital images taken from film autoradiograms. Scale bar $=3 \mathrm{~mm}$.

Figure 2.- Detection of GIRK1-3 subunits immunoreactivity in rat brain cortical membranes. A1. Representative immunoblotting of GIRK1 subunits in samples of cortical membranes without (lanes 1,2 and 3 on the right) and after preincubation with the synthetic peptide used as the immunogen (lanes 4, 5 and 6 on the left). A2. GIRK1 appears as a triplet, with the three bands representing differentially glycosylated versions of the core polypeptide. Standard curves for the $60 \mathrm{KDa}$ version of the GIRK1 subunits were generated with incremental amounts of total membrane protein ranging from 1 to $6 \mu \mathrm{g}$. A3. The correlation coefficient was obtained by linear regression analysis and was $r^{2}=0.9720$. B1. Representative Western blots of GIRK2 subunit. Note that immunoblots labelled with anti-GIRK2 exhibited two positive bands (right), of which only the $75 \mathrm{KDa}$ band disappeared after preincubation with the synthetic peptide used as the immunogen (left). B2-B3. Immunoblotting with incremental amounts of protein ranging from 2.5 to $20 \mu \mathrm{g}$, allowed to obtain the corresponding standard curves from which the correlation coefficient $\left(r^{2}=0.9879\right)$ was estimated by linear regression analysis. C1. Representative Western blots of GIRK3 subunit immunoreactivity in samples of cortical membranes without (right) and after preincubation with the blocking peptide (left). C2. Standard curves were generated by immunoblotting using incremental amounts of total membrane protein ranging from 5 to $40 \mu \mathrm{g}$. C3. The correlation coefficient was obtained by linear regression analysis and was $r^{2}=0.9664$. 
The positions of molecular weight markers are indicated on the left in A1, B1 and C1.

Figure 3.- Regional distribution of the different GIRK subunit mRNAs and 5-HT $1 \mathrm{~A}$ mRNA in consecutive sections of the rat brain at different rostrocaudal levels. Autoradiographic images show GIRK1 (A1-G1), GIRK2 (A2-G2), GIRK3 (A3-G3) and 5- $\mathrm{HT}_{1 \mathrm{~A}}$ receptor (A4-G4) mRNAs visualized by in situ hybridization with the corresponding ${ }^{33} \mathrm{P}$-labeled oligonucleotides. Pictures are digital photographs from film autoradiograms. A5-G5 show photographs of a Nissl stained section for each level. Scale bar $=3 \mathrm{~mm}$.

Figure 4.- Laminar distribution of GIRK subunit mRNAs and detail of positively immunostained neural cells in the rat frontal cortex. Dark-field photomicrographs from emulsion-dipped coronal sections through cortical layers indicated by roman numbers where GIRK1 (A1), GIRK2 (B1) and GIRK3 (C1) mRNA-containing cells (white silver grains) appear localized in the different layers. Detail of GIRK1-IR cells in layer V (A2), GIRK2- IR cells in layer V (B2) and GIRK3-IR cells in layer III (C3). Scale bars = 400 $\mu \mathrm{m}$ in $\mathrm{A} 1-\mathrm{C} 1 ; 20 \mu \mathrm{m}$ in A2-C2.

Figure 5.- Expression of GIRK subunit and 5- $\mathrm{HT}_{1 \mathrm{~A}}$ receptor mRNAs and detail of positively immunostained neurons in rat hippocampus. Dark-field photomicrographs from emulsion-dipped coronal sections through the hippocampal region showing the presence of mRNA coding for GIRK1 (A1), GIRK2 (B1), GIRK3 (C1) and 5-HT1A (D1). Detail of GIRK1-IR cells in the hilus of the dentate gyrus (A2), GIRK2-IR cells in the CA3 field (B2), GIRK3-IR cells in the CA1 field (C2) and 5- $\mathrm{HT}_{1 \mathrm{~A}}$ receptor-IR cells in the CA3 field of the hippocampus (D2). Scale bars $=400 \mu \mathrm{m}$ in A1-D1; $20 \mu \mathrm{m}$ in A2-D2.

Figure 6.- Expression of GIRK subunit mRNAs in emulsion-dipped sections and detail of positively immunostained neurons in rat habenular nuclei. Dark-field photomicrographs from coronal sections through the habenular region showing the presence of mRNA coding for GIRK1 (A1, A2), GIRK2 (B1, B2) and GIRK3 (C1, C2). A2, B2 and C2 are higher magnification photomicrographs of the medial habenular nucleus. Detail of GIRK1-IR cells in the medial habenular nucleus (A3), GIRK2-IR cells in the lateral habenular nucleus (B3) and GIRK3-IR cells in the medial habenular nucleus (C3). Scale bars $=400 \mu \mathrm{m}$ in A1-C1; $50 \mu \mathrm{m}$ in A2-C2; $20 \mu \mathrm{m}$ in A3-C3. 
Figure 7.- Distribution of GIRK subunit mRNAs in the rat thalamus as observed on emulsion-dipped sections under dark-field illumination. Photographs show GIRK1 (A1A3), GIRK2 (B1-B3) and GIRK3 (C1-C3) mRNAs. Scale bars $=400 \mu \mathrm{m}$ in A1-C1; 100 $\mu \mathrm{m}$ in $\mathrm{A} 2-\mathrm{C} 2 ; 50 \mu \mathrm{m}$ in $\mathrm{A} 3-\mathrm{C} 3$.

Figure 8.- Bright-field photomicrographs showing GIRK1 subunit positively immunostained neurons in the supraoptic nucleus (A1, A2) and the paraventricular nucleus of the hypothalamus (B1, B2). Scale bar $=100 \mu \mathrm{m}$ in A1-B1; $20 \mu \mathrm{m}$ in A2-B2.

Figure 9.- Distribution of GIRK subunit mRNAs in the rat cerebellum. Emulsion-dipped sections show GIRK1 (A1-A3), GIRK2 (B1-B3) and GIRK3 (C1-C3) mRNAs. A3-C3 illustrate cresyl violet staining in the same labeled sections showed in A2-C2, respectively. Arrowheads in A2-C2 and A3-C3 point to Purkinje cells. Note the absence of GIRK1 mRNA in Punkinje cells in A2 and A3. Scale bars $=400 \mu \mathrm{m}$ in A1-C1; $50 \mu \mathrm{m}$ in $\mathrm{A} 2-\mathrm{C} 2$ and $\mathrm{A} 3-\mathrm{C} 3$.

Figure 10.- Detail of GIRK2 subunit-immunostained neurons for the in the rat red nucleus (A1, A2). Scale bars $=100 \mu \mathrm{m}$ in A1;20 $\mu \mathrm{m}$ in A2.

Figure 11.- GIRK2 immunoreactive neural cells in the rat substantia nigra (A) and a dark-field photomicrograph of this area showing the presence of mRNA coding for GIRK2 (B). Detail of neural cell bodies in the substantia nigra compact part (C) and reticular part (D). Scale bars $=100 \mu \mathrm{m}$ in $\mathrm{A}, \mathrm{B} ; 20 \mu \mathrm{m}$ in $\mathrm{C}$ and $\mathrm{D}$.

Figure 12.- High-magnification photomicrographs showing the simultaneous detection of two GIRK mRNAs in different brain areas. One of the subunits was detected by using ${ }^{33} \mathrm{P}$-labeled oligonucleotides $\left({ }^{33} \mathrm{P}\right)$ and the other with digoxigenin-labeled probes (Dig) as indicated. Photomicrographs were taken from the dentate gyrus (A-C), the pyramidal layer of the hippocampus (CA1 field) (D-F), the parietal cortex (G-I) and the thalamus (J-L). White arrowheads point to single Dig-labeled cells. Black arrowheads point to single ${ }^{33} \mathrm{P}$-labeled cells. Black-and-white arrowheads point to double-labeled cells. Scale bar $=10 \mu \mathrm{m}$. 
Figure 13.- High-magnification photomicrographs showing the simultaneous detection of two species of mRNA using Dig- labeled probes for vGluT mRNA and ${ }^{33}$ P-labeled oligonucleotide probes for the mRNA of GIRK subunits GIRK1 (A1-D1), GIRK2 (A2-D2) and GIRK3 (A3-D3) in the dentate gyrus of the hippocampus (A1-A3), pyramidal layer of the hippocampus (CA1 field) (B1-B3), parietal cortex (C1-C3) and thalamus (D1-D3). White arrowheads point to single Dig-labeled cells. Black arrowheads point to single ${ }^{33} \mathrm{P}$-labeled cells. Black-and-white arrowheads point to double-labeled cells. Scale bar = $20 \mu \mathrm{m}$.

Figure 14.- High-magnification photomicrographs showing the simultaneous detection of two species of mRNA using Dig- labeled probes for GAD mRNA and ${ }^{33}$ P-labeled oligonucleotide probes for the mRNA of GIRK subunits GIRK1 (A1-D1), GIRK2 (A2-D2) and GIRK3 (A3-D3) mRNA in the dentate gyrus of the hippocampus (A1-A3), pyramidal layer of the hippocampus (CA1 field) (B1-B3), parietal cortex (C1-C3), and reticular thalamic nucleus (D1-D3). White arrowheads point to single Dig-labeled cells. Black arrowheads point to single ${ }^{33} \mathrm{P}$-labeled cells. Black-and-white arrowheads point to double-labeled cells. Scale bar $=20 \mu \mathrm{m}$.

Figure 15.- High-magnification photomicrographs showing the simultaneous detection of two species of mRNA using ${ }^{33}$ P-labeled oligonucleotide probes for GIRK1 (A-D) and GIRK2 (E-H) subunits (silver grains) and Dig- labeled probes for ChAT mRNA in the nucleus of the vertical limb of the diagonal band. White arrowheads point to single Diglabeled cells. Black arrowheads point to single ${ }^{33} \mathrm{P}$-labeled cells. Black-and-white arrowheads point to double-labeled cells. Scale bar $=20 \mu \mathrm{m}$.

Figure 16.- High-magnification photomicrographs showing the simultaneous detection of two species of mRNA using ${ }^{33} \mathrm{P}$-labeled oligonucleotide probes for the serotonin receptor $5-\mathrm{HT}_{1 \mathrm{~A}}$ (silver grains) and Dig- labeled probes for the mRNAs of GIRK subunits: GIRK1 (A1-E1), GIRK2 (A2-E2) and GIRK3 (A3-E3) in the dentate gyrus of the hippocampus (A1-A3), pyramidal layer of the hippocampus (CA1 field) (B1-B3), parietal cortex (C1-C3), septum (D1-D3), dorsal raphe nucleus (E1-E3). White arrowheads point to single Dig-labeled cells. Black arrowheads point to single ${ }^{33} \mathrm{P}$ labeled cells. Black-and-white arrowheads point to double-labeled cells. Scale bar $=20$ $\mu \mathrm{m}$. 
Figure 17.- High-magnification photomicrographs showing the simultaneous detection of two species of mRNA using ${ }^{33} \mathrm{P}$-labeled oligonucleotide probes for GIRK1 (A), GIRK2 (B) and GIRK3 (C) subunits (silver grains) and Dig-labeled probes for the serotonin transporter mRNA in the dorsal raphe nucleus. White arrowheads point to single Dig-labeled cells. White arrowheads point to single Dig-labeled cells. Black arrowheads point to single ${ }^{33} \mathrm{P}$-labeled cells. Black-and-white arrowheads point to double-labeled cells. Scale bar $=20 \mu \mathrm{m}$. 


\section{TABLE OF ABBREVIATIONS}

AD anterodorsal thalamic nucleus

APTS 3-aminopropyltriethoxysilane

Arc arcuate nucleus

CA1 field CA1 of hippocampus

CA2 field CA2 of hippocampus

CA3 field CA3 of hippocampus

ChAT choline acetyl transferase

$\mathrm{CM} \quad$ central medial thalamic nucleus

$\mathrm{CPu} \quad$ caudate-putamen

DG dentate gyrus of the hippocampus

Dig digoxigenin

$\mathrm{DMH}$ dorsomedial hypothalamic area

DR dorsal raphe nucleus

DS dorsal septal nucleus

ECL enhanced chemiluminiscence system

ER endoplasmic reticulum

GAD glutamic acid descarboxylase

GIRK G-protein inwardly rectifying potassium channel (Kir3)

GL granular cell layer of cerebellum

5-HT serotonin

IC inferior colliculus

ICM major island of Calleja

IG indusium griseum

IP interpeduncular nucleus

IPSP inhibitory postsynaptic potential

IR immunoreactive or immunoreactivity

Kir3 G-protein inwardly rectifying potassium channel (GIRK)

LC locus coeruleus

LDDM laterodorsal thalamic nucleus, dorsomedial part

LDVL laterodorsal thalamic nucleus, ventrolateral part

$\mathrm{LHb} \quad$ lateral habenular nucleus

MG medial geniculate nucleus 


$\begin{array}{ll}\text { MHb } & \text { medial habenular nucleus } \\ \text { MnR } & \text { median raphe nucleus } \\ \text { MS } & \text { medial septal nucleus } \\ \text { NGS } & \text { normal goat serum } \\ \text { Pa } & \text { paraventricular nucleus } \\ \text { PFCx } & \text { prefrontal cortex } \\ \text { Pir } & \text { piriform cortex } \\ \text { PK } & \text { Purkinje cell layer } \\ \text { Pn } & \text { pontine nuclei } \\ \text { Rt } & \text { reticular thalamic nucleus } \\ \text { SDS } & \text { sodium dodecyl sulfate } \\ \text { SNC } & \text { substantia nigra, compact part } \\ \text { SNR } & \text { substantia nigra, reticular part } \\ \text { SO } & \text { supraoptic nucleus } \\ \text { ST } & \text { serotonin transporter } \\ \text { Ts65Dn } & \text { segmental tryisomy 16, Down syndrome model } \\ \text { Tu } & \text { olfactory tubercle } \\ \text { VDB } & \text { nucleus of the vertical limb of the diagonal band } \\ \text { vGluT } & \text { vesicular glutamate transporter } \\ \text { VMH } & \text { ventromedial hypothalamic nucleus } \\ \text { VS } & \text { ventral septal nucleus } \\ \text { Wv } & \text { weaver mouse } \\ \text { ZI } & \text { zona incerta } \\ & \end{array}$




\section{TABLES}

Table 1.- Estimated densities of immunoreactive cells and of mRNAs encoding GIRK subunits and $5-\mathrm{HT}_{1 \mathrm{~A}}$ receptor in different regions of the rat brain.

The relative abundance of immunostained cell bodies is indicated as: "++++" very abundant (more than 2500 labeled elements $/ \mathrm{mm}^{2}$ ); “+++" abundant (1500-2500 labeled elements $/ \mathrm{mm}^{2}$ ); “++" moderate expression (1000-1500 labeled elements $/ \mathrm{mm}^{2}$ ); "+" low expression (less than 1000 labeled elements $/ \mathrm{mm}^{2}$ ); “-“ consistent absence of detectable staining; "n.d" not determined.

The relative densities of labeled mRNAs obtained by semiquantification of film autoradiograms are expressed as: "+++" very high (relative optical density higher than 0.5); "++" moderate (relative optical density from 0.35 to 0.5 ); "+" low (relative optical density lower than 0.35); "-“ very low or undetectable; "n.d” not determined. 


\section{Reference List}

Andrade R, Malenka RC, Nicoll RA. 1986. A G protein couples serotonin and GABAB receptors to the same channels in hippocampus. Science 234:1261-1265.

Andrade R, Nicoll RA. 1987. Pharmacologically distinct actions of serotonin on single pyramidal neurones of the rat hippocampus recorded in vitro. J Physiol 394:99-124.

Bausch SB, Patterson TA, Ehrengruber MU, Lester HA, Davidson N, Chavkin C. 1995. Colocalization of mu opioid receptors with GIRK1 potassium channels in the rat brain: an immunocytochemical study. Receptors Channels 3:221-241.

Blednov YA, Stoffel M, Chang SR, Harris RA. 2001. GIRK2 deficient mice. Evidence for hyperactivity and reduced anxiety. Physiol Behav 74:109-117.

Brown AM, Birnbaumer L. 1990. Ionic channels and their regulation by G-protein subunits. Annu Rev Physiol 52:197-213.

Chalmers DT, Watson SJ. 1991. Comparative anatomical distribution of 5-HT1A receptor mRNA and 5-HT1A binding in rat brain: a combined in situ hybridisation/in vitro receptor autoradiographic study. Brain Res 561:51-60.

Chan KW, Sui JL, Vivaudou M, Logothetis DE. 1996. Control of channel activity through a unique amino acid residue of a $\mathrm{G}$ protein-gated inwardly rectifying $\mathrm{K}^{+}$channel subunit. Proc Natl Acad Sci U S A 93:14193-14198.

Chan KW, Sui JL, Vivaudou M, Logothetis DE. 1997. Specific regions of heteromeric subunits involved in enhancement of $\mathrm{G}$ protein-gated $\mathrm{K}^{+}$channel activity. $\mathrm{J}$ Biol Chem 272:6548-6555.

Cho H, Lee D, Lee SH, Ho WK. 2005. Receptor-induced depletion of phosphatidylinositol 4,5-bisphosphate inhibits inwardly rectifying $\mathrm{K}^{+}$channels in a receptor-specific manner. Proc Natl Acad Sci U S A 102:4643-4648.

Colino A, Halliwell JV. 1987. Differential modulation of three separate K-conductances in hippocampal CA1 neurons by serotonin. Nature 328:73-77.

Collin M, Backberg M, Onnestam K, Meister B. 2002. 5-HT1A receptor immunoreactivity in hypothalamic neurons involved in body weight control. Neuroreport 13:945-951.

Corey S, Clapham DE. 1998. Identification of native atrial G-protein-regulated inwardly rectifying $\mathrm{K}^{+}$(GIRK4) channel homomultimers. J Biol Chem 273:27499-27504.

Dascal N. 1997. Signalling via the G protein-activated $\mathrm{K}^{+}$channels. Cell Signal 9:551573.

Davisson MT, Schmidt C, Akeson EC. 1990. Segmental trisomy of murine chromosome 16: a new model system for studying Down syndrome. Prog Clin Biol Res 360:263-280.

DePaoli AM, Bell GI, Stoffel M. 1994. G protein-activated inwardly rectifying potassium 
channel (GIRK1/KGA) mRNA in adult rat heart and brain by in situ hybridization histochemistry. Mol Cell Neurosci 5:515-522.

Deutsch C. 2002. Potassium channel ontogeny. Annu Rev Physiol 64:19-46.

Dierssen M, Vallina IF, Baamonde C, Garcia-Calatayud S, Lumbreras MA, Florez J. 1997. Alterations of central noradrenergic transmission in Ts65Dn mouse, a model for Down syndrome. Brain Res 749:238-244.

Drake CT, Bausch SB, Milner TA, Chavkin C. 1997. GIRK1 immunoreactivity is present predominantly in dendrites, dendritic spines, and somata in the CA1 region of the hippocampus. Proc Natl Acad Sci U S A 94:1007-1012.

Fujita M, Shimada S, Maeno H, Nishimura T, Tohyama M. 1993. Cellular localization of serotonin transporter mRNA in the rat brain. Neurosci Lett 162:59-62.

Garro MA, Lopez dJ, Callado LF, Meana JJ, Salles J. 2001. Regulation of phospholipase Cbeta activity by muscarinic acetylcholine and 5-HT(2) receptors in crude and synaptosomal membranes from human cerebral cortex. Neuropharmacology 40:686-695.

Grosse G, Eulitz D, Thiele T, Pahner I, Schroter S, Takamori S, Grosse J, Wickman K, Tapp R, Veh RW, Ottersen OP, Ahnert-Hilger G. 2003. Axonal sorting of Kir3.3 defines a GABA-containing neuron in the CA3 region of rodent hippocampus. Mol Cell Neurosci 24:709-724.

Harashima C, Jacobowitz DM, Witta J, Borke RC, Best TK, Siarey RJ, Galdzicki Z. 2006. Abnormal expression of the G-protein activated inwardly rectifying potassium channel 2 (GIRK2) in hippocampus, frontal cortex, and substantia nigra of Ts65Dn mouse: a model of Down syndrome. J Comp Neurol 494:815-833.

He C, Yan X, Zhang H, Mirshahi T, Jin T, Huang A, Logothetis DE. 2002. Identification of critical residues controlling $\mathrm{G}$ protein-gated inwardly rectifying $\mathrm{K}^{+}$channel activity through interactions with the beta gamma subunits of $\mathrm{G}$ proteins. J Biol Chem 277:6088-6096.

Hille B. 1992. G protein-coupled mechanisms and nervous signaling. Neuron 9:187195.

Ho IH, Murrell-Lagnado RD. 1999. Molecular mechanism for sodium-dependent activation of $\mathrm{G}$ protein-gated $\mathrm{K}^{+}$channels. J Physiol 520 Pt 3:645-651.

Huang CL, Feng S, Hilgemann DW. 1998. Direct activation of inward rectifier potassium channels by PIP2 and its stabilization by Gbetagamma. Nature 391:803-806.

Inanobe A, Yoshimoto $\mathrm{Y}$, Horio $\mathrm{Y}$, Morishige $\mathrm{KI}$, Hibino $\mathrm{H}$, Matsumoto S, Tokunaga $\mathrm{Y}$, Maeda T, Hata Y, Takai Y, Kurachi Y. 1999. Characterization of G-protein-gated $\mathrm{K}^{+}$ channels composed of Kir3.2 subunits in dopaminergic neurons of the substantia nigra. J Neurosci 19:1006-1017.

Isomoto S, Kondo C, Takahashi N, Matsumoto S, Yamada M, Takumi T, Horio Y, Kurachi Y. 1996. A novel ubiquitously distributed isoform of GIRK2 (GIRK2b) enhances GIRK1 expression of the G-protein-gated $\mathrm{K}^{+}$current in Xenopus oocytes. Biochem 
Biophys Res Commun 218:286-291.

Jan LY, Jan YN. 1997. Cloned potassium channels from eukaryotes and prokaryotes. Annu Rev Neurosci 20:91-123.

Jelacic TM, Kennedy ME, Wickman K, Clapham DE. 2000. Functional and biochemical evidence for G-protein-gated inwardly rectifying $\mathrm{K}^{+}(\mathrm{GIRK})$ channels composed of GIRK2 and GIRK3. J Biol Chem 275:36211-36216.

Kaneko T, Fujiyama F, Hioki H. 2002. Immunohistochemical localization of candidates for vesicular glutamate transporters in the rat brain. J Comp Neurol 444:39-62.

Karschin A. 1999. G Protein Regulation of Inwardly Rectifying $\mathrm{K}^{+}$Channels. News Physiol Sci 14:215-220.

Karschin C, Dissmann E, Stuhmer W, Karschin A. 1996. IRK(1-3) and GIRK(1-4) inwardly rectifying $\mathrm{K}^{+}$channel mRNAs are differentially expressed in the adult rat brain. J Neurosci 16:3559-3570.

Karschin C, Schreibmayer W, Dascal N, Lester H, Davidson N, Karschin A. 1994. Distribution and localization of a $\mathrm{G}$ protein-coupled inwardly rectifying $\mathrm{K}^{+}$channel in the rat. FEBS Lett 348:139-144.

Kennedy ME, Nemec J, Corey S, Wickman K, Clapham DE. 1999. GIRK4 confers appropriate processing and cell surface localization to G-protein-gated potassium channels. J Biol Chem 274:2571-2582.

Kia HK, Miquel MC, Brisorgueil MJ, Daval G, Riad M, el MS, Hamon M, Verge D. 1996. Immunocytochemical localization of serotonin $1 \mathrm{~A}$ receptors in the rat central nervous system. J Comp Neurol 365:289-305.

Kim KM, Nakajima Y, Nakajima S. 1995. G protein-coupled inward rectifier modulated by dopamine agonists in cultured substantia nigra neurons. Neuroscience 69:11451158.

Kobayashi T, Ikeda K, Ichikawa T, Abe S, Togashi S, Kumanishi T. 1995. Molecular cloning of a mouse G-protein-activated $\mathrm{K}^{+}$channel (mGIRK1) and distinct distributions of three GIRK (GIRK1, 2 and 3) mRNAs in mouse brain. Biochem Biophys Res Commun 208:1166-1173.

Kobayashi T, Washiyama K, Ikeda K. 2003. Inhibition of G protein-activated inwardly rectifying $\mathrm{K}+$ channels by fluoxetine (Prozac). Br J Pharmacol 138:1119-1128.

Kobayashi T, Washiyama K, Ikeda K. 2004. Inhibition of G protein-activated inwardly rectifying $\mathrm{K}+$ channels by various antidepressant drugs. Neuropsychopharmacology 29:1841-1851.

Kobayashi T, Washiyama K, Ikeda K. 2006. Inhibition of G protein-activated inwardly rectifying K+ channels by ifenprodil. Neuropsychopharmacology 31:516-524.

Koyrakh L, Lujan R, Colon J, Karschin C, Kurachi Y, Karschin A, Wickman K. 2005. Molecular and cellular diversity of neuronal G-protein-gated potassium channels. J Neurosci 25:11468-11478. 
Krapivinsky G, Gordon EA, Wickman K, Velimirovic B, Krapivinsky L, Clapham DE. 1995. The G-protein-gated atrial $\mathrm{K}^{+}$channel IKACh is a heteromultimer of two inwardly rectifying $\mathrm{K}^{+}$channel proteins. Nature 374:135-141.

Landry M, Holmberg K, Zhang X, Hokfelt T. 2000. Effect of axotomy on expression of NPY, galanin, and NPY Y1 and Y2 receptors in dorsal root ganglia and the superior cervical ganglion studied with double-labeling in situ hybridization and immunohistochemistry. Exp Neurol 162:361-384.

Leaney JL. 2003. Contribution of Kir3.1, Kir3.2A and Kir3.2C subunits to native G protein-gated inwardly rectifying potassium currents in cultured hippocampal neurons. Eur J Neurosci 18:2110-2118.

Lesage F, Duprat F, Fink M, Guillemare E, Coppola T, Lazdunski M, Hugnot JP. 1994. Cloning provides evidence for a family of inward rectifier and G-protein coupled $\mathrm{K}^{+}$ channels in the brain. FEBS Lett 353:37-42.

Lesage F, Guillemare E, Fink M, Duprat F, Heurteaux C, Fosset M, Romey G, Barhanin J, Lazdunski M. 1995. Molecular properties of neuronal G-protein-activated inwardly rectifying $\mathrm{K}^{+}$channels. J Biol Chem 270:28660-28667.

Liao YJ, Jan YN, Jan LY. 1996. Heteromultimerization of G-protein-gated inwardly rectifying $\mathrm{K}^{+}$channel proteins GIRK1 and GIRK2 and their altered expression in weaver brain. J Neurosci 16:7137-7150.

Logothetis DE, Kurachi Y, Galper J, Neer EJ, Clapham DE. 1987. The beta gamma subunits of GTP-binding proteins activate the muscarinic $\mathrm{K}^{+}$channel in heart. Nature 325:321-326.

Lopes CM, Zhang H, Rohacs T, Jin T, Yang J, Logothetis DE. 2002. Alterations in conserved Kir channel-PIP2 interactions underlie channelopathies. Neuron 34:933-944.

Luscher C, Jan LY, Stoffel M, Malenka RC, Nicoll RA. 1997. G protein-coupled inwardly rectifying $\mathrm{K}+$ channels (GIRKs) mediate postsynaptic but not presynaptic transmitter actions in hippocampal neurons. Neuron 19:687-695.

Ma D, Jan LY. 2002. ER transport signals and trafficking of potassium channels and receptors. Curr Opin Neurobiol 12:287-292.

Ma D, Zerangue N, Lin YF, Collins A, Yu M, Jan YN, Jan LY. 2001. Role of ER export signals in controlling surface potassium channel numbers. Science 291:316-319.

Ma D, Zerangue N, Raab-Graham K, Fried SR, Jan YN, Jan LY. 2002. Diverse trafficking patterns due to multiple traffic motifs in $G$ protein-activated inwardly rectifying potassium channels from brain and heart. Neuron 33:715-729.

Mao J, Li L, McManus M, Wu J, Cui N, Jiang C. 2002. Molecular determinants for activation of G-protein-coupled inward rectifier K+ (GIRK) channels by extracellular acidosis. J Biol Chem 277:46166-46171.

Mirshahi T, Logothetis DE. 2004. Molecular determinants responsible for differential cellular distribution of $\mathrm{G}$ protein-gated inwardly rectifying $\mathrm{K}^{+}$channels. J Biol Chem 279:11890-11897. 
Miyashita T, Kubo Y. 1997. Localization and developmental changes of the expression of two inward rectifying $\mathrm{K}^{+}$channel proteins in the rat brain. Brain Res 750:251-263.

Morgan AD, Carroll ME, Loth AK, Stoffel M, Wickman K. 2003. Decreased cocaine selfadministration in Kir3 potassium channel subunit knockout mice.

Neuropsychopharmacology 28:932-938.

Murer G, Adelbrecht C, Lauritzen I, Lesage F, Lazdunski M, Agid Y, Raisman-Vozari R. 1997. An immunocytochemical study on the distribution of two G-protein-gated inward rectifier potassium channels (GIRK2 and GIRK4) in the adult rat brain. Neuroscience 80:345-357.

Neer EJ. 1995. Heterotrimeric G proteins: organizers of transmembrane signals. Cell 80:249-257.

Nicoll RA. 1988. The coupling of neurotransmitter receptors to ion channels in the brain. Science 241:545-551.

North RA. 1989. Twelfth Gaddum memorial lecture. Drug receptors and the inhibition of nerve cells. Br J Pharmacol 98:13-28.

Patil N, Cox DR, Bhat D, Faham M, Myers RM, Peterson AS. 1995. A potassium channel mutation in weaver mice implicates membrane excitability in granule cell differentiation. Nat Genet 11:126-129.

Paxinos $G$ and Watson C. 1998. The Rat Brain in stereotaxic coordinates. San Diego: Academic Press.

Penington NJ, Kelly JS, Fox AP. 1993. Whole-cell recordings of inwardly rectifying $\mathrm{K}^{+}$ currents activated by 5-HT1A receptors on dorsal raphe neurones of the adult rat. $\mathrm{J}$ Physiol 469:387-405.

Pompeiano M, Palacios JM, Mengod G. 1992. Distribution and cellular localization of messenger-RNA coding for 5-HT1A receptor in the rat brain. Correlation with receptorbinding. Journal of Neuroscience 12:440-453.

Ponce A, Bueno E, Kentros C, Vega-Saenz de Miera E, Chow A, Hillman D, Chen S, Zhu L, Wu MB, Wu X, Rudy B, Thornhill WB. 1996. G-protein-gated inward rectifier $\mathrm{K}^{+}$ channel proteins (GIRK1) are present in the soma and dendrites as well as in nerve terminals of specific neurons in the brain. J Neurosci 16:1990-2001.

Rossi P, De Filippi G, Armano S, Taglietti V, D'Angelo E. 1998. The weaver mutation causes a loss of inward rectifier current regulation in premigratory granule cells of the mouse cerebellum. J Neurosci 18:3537-3547.

Ruiz de Azua I, Zalduegui A, Baamonde C, Dierssen M, Florez J, Salles J. 2001.

Reduced phospholipase C-beta activity and isoform expression in the cerebellum of TS65Dn mouse: a model of Down syndrome. J Neurosci Res 66:540-550.

Salles J, Lopez de Jesus M, Goni O, Fernandez-Teruel A, Driscoll P, Tobena A, Escorihuela RM. 2001. Transmembrane signaling through phospholipase $C$ in cortical and hippocampal membranes of psychogenetically selected rat lines.

Psychopharmacology (Berl) 154:115-125. 
Schmitz GG, Walter T, Seibl R, Kessler C. 1991. Nonradioactive labeling of oligonucleotides in vitro with the hapten digoxigenin by tailing with terminal transferase. Anal Biochem 192:222-231.

Serrats J, Artigas F, Mengod G, Cortes R. 2003. GABAB receptor mRNA in the raphe nuclei: co-expression with serotonin transporter and glutamic acid decarboxylase. J Neurochem 84:743-752.

Slesinger PA, Stoffel M, Jan YN, Jan LY. 1997. Defective gamma-aminobutyric acid type $\mathrm{B}$ receptor-activated inwardly rectifying $\mathrm{K}^{+}$currents in the cerebellar granule cells isolated from weaver and GIRK2 null mutant mice. Proc Natl Acad Sci U S A 94:1221012217.

Soghomonian JJ, Martin DL. 1998. Two isoforms of glutamate decarboxylase: why? Trends Pharmacol Sci 19:500-505.

Sui JL, Petit-Jacques J, Logothetis DE. 1998. Activation of the atrial KACh channel by the betagamma subunits of $\mathrm{G}$ proteins or intracellular $\mathrm{Na}^{+}$ions depends on the presence of phosphatidylinositol phosphates. Proc Natl Acad Sci U S A 95:1307-1312.

Tomiyama M, Palacios JM, Cortes R, Vilaro MT, Mengod G. 1997. Distribution of AMPA receptor subunit mRNAs in the human basal ganglia: an in situ hybridization study. Mol Brain Res 46:281-289.

Torrecilla M, Marker CL, Cintora SC, Stoffel M, Williams JT, Wickman K. 2002. Gprotein-gated potassium channels containing Kir3.2 and Kir3.3 subunits mediate the acute inhibitory effects of opioids on locus coeruleus neurons. J Neurosci 22:43284334.

Wickman K, Clapham DE. 1995. Ion channel regulation by G proteins. Physiol Rev 75:865-885.

Woodward R, Stevens EB, Murrell-Lagnado RD. 1997. Molecular determinants for assembly of $\mathrm{G}$-protein-activated inwardly rectifying $\mathrm{K}^{+}$channels. J Biol Chem 272:10823-10830.

Yamada M, Inanobe A, Kurachi Y. 1998. G protein regulation of potassium ion channels. Pharmacol Rev 50:723-760.

Yang J, Jan YN, Jan LY. 1995. Determination of the subunit stoichiometry of an inwardly rectifying potassium channel. Neuron 15:1441-1447.

Zgombick JM, Beck SG, Mahle CD, Craddock-Royal B, Maayani S. 1989. Pertussis toxin-sensitive guanine nucleotide-binding protein(S) couple adenosine A1 and 5hydroxytryptamine1A receptors to the same effector systems in rat hippocampus: biochemical and electrophysiological studies. Mol Pharmacol 35:484-494. 
Table 1. Estimated densities of immunoreactive cells and of mRNAs encoding GIRK subunits and $5-\mathrm{HT}_{1 \mathrm{~A}}$ receptor in different regions of the rat brain.

\begin{tabular}{|c|c|c|c|c|c|c|c|c|}
\hline \multirow{2}{*}{ Brain area } & \multicolumn{2}{|c|}{ GIRK1 } & \multicolumn{2}{|c|}{ GIRK2 } & \multicolumn{2}{|c|}{ GIRK3 } & \multicolumn{2}{|c|}{$5 \mathrm{HT}_{1 \mathrm{~A}}$} \\
\hline & Protein & mRNA & Protein & mRNA & Protein & mRNA & Protein & mRNA \\
\hline \multicolumn{9}{|l|}{$\begin{array}{l}\text { Primary cortical areas } \\
\text { (Motor, Somatosensory, } \\
\text { Auditory, Visual cortices) }\end{array}$} \\
\hline Layer I & - & - & $\begin{array}{l}\text { intense } \\
\text { neuropil }\end{array}$ & - & - & - & - & - \\
\hline Layer II-III & +++ & ++ & $\begin{array}{l}\text { abundant } \\
\text { fibres }\end{array}$ & ++ & +++ & ++ & ++ & - \\
\hline Layer IV & +++ & +++ & + & ++ & ++ & +++ & ++ & - \\
\hline Layer V & +++ & ++ & +++ & ++ & ++ & ++ & +++ & + \\
\hline Layer VI & +++ & ++ & +++ & ++ & ++ & ++ & +++ & + \\
\hline \multicolumn{9}{|l|}{$\begin{array}{l}\text { Prelimbic, Infralimbic, } \\
\text { anterior Cingulate, Insular } \\
\text { and Orbital Cortices, and } \\
\text { Parietal and Temporal } \\
\text { association cortical areas }\end{array}$} \\
\hline Layer I & - & - & $\begin{array}{l}\text { intense } \\
\text { neuropil }\end{array}$ & - & - & - & - & - \\
\hline Layers II-VI & ++ & ++ & $\begin{array}{l}\text { abundant } \\
\text { fibres }\end{array}$ & ++ & ++ & ++ & ++ & - \\
\hline Piriform cortex & ++++ & +++ & ++++ & +++ & +++ & ++ & ++ & + \\
\hline \multicolumn{9}{|l|}{$\begin{array}{l}\text { Entorhinal and } \\
\text { Retrosplenial Cortices }\end{array}$} \\
\hline Layer II & ++ & +++ & $\begin{array}{l}\text { abundant } \\
\text { fibres }\end{array}$ & ++ & ++ & $++/+++$ & ++ & ++ \\
\hline Inner layers & ++ & $+/++$ & $\begin{array}{l}\text { abundant } \\
\text { fibres }\end{array}$ & ++ & ++ & $+/++$ & ++ & + \\
\hline $\begin{array}{l}\text { Hippocampus and related } \\
\text { areas }\end{array}$ & & & $\begin{array}{l}\text { intense } \\
\text { neuropil }\end{array}$ & & & & & \\
\hline Dentate gyrus & ++++ & +++ & ++++ & +++ & ++++ & ++ & ++++ & +++ \\
\hline \multicolumn{9}{|l|}{ Ammon's horn } \\
\hline CA1 & +++ & +++ & +++ & +++ & +++ & ++ & ++ & ++ \\
\hline CA2 & +++ & +++ & +++ & +++ & +++ & ++ & ++ & ++ \\
\hline CA3 & +++ & +++ & +++ & +++ & +++ & ++ & +++ & ++ \\
\hline $\begin{array}{l}\text { Subiculum and } \\
\text { presubiculum }\end{array}$ & +++ & +++ & ++ & ++ & ++ & ++ & & \\
\hline Taenia tecta & +++ & n.d & +++ & n.d & ++ & n.d & + & n.d \\
\hline \multicolumn{9}{|l|}{$\begin{array}{l}\text { Septum and Diagonal } \\
\text { Band }\end{array}$} \\
\hline Ventral septal nucleus & +++ & + & $\begin{array}{c}\text { abundant } \\
\text { fibres }\end{array}$ & ++ & $\begin{array}{c}\text { abundant } \\
\text { fibres. }\end{array}$ & + & n.d & ++ \\
\hline Medial septal nucleus & +++ & + & $\begin{array}{l}\text { abundant } \\
\text { fibres }\end{array}$ & ++ & $\begin{array}{l}\text { abundant } \\
\text { fibres }\end{array}$ & + & + & ++ \\
\hline Dorsal septal nucleus & ++ & + & $\begin{array}{l}\text { abundant } \\
\text { fibres }\end{array}$ & ++ & $\begin{array}{l}\text { abundant } \\
\text { fibres }\end{array}$ & + & n.d & ++ \\
\hline $\begin{array}{l}\text { Ventral limb of the } \\
\text { diagonal band }\end{array}$ & ++ & + & +++ & ++ & +++ & + & + & - \\
\hline \multicolumn{9}{|l|}{ Basal Ganglia } \\
\hline Caudate-putamen & +++ & + & - & + & ++ & + & + & - \\
\hline Globus pallidus & + & - & + & - & - & - & - & - \\
\hline Amygdala & ++ & + & - & ++ & +++ & + & ++ & - \\
\hline Epithalamus & & & $\begin{array}{l}\text { abundant } \\
\text { fibres }\end{array}$ & & & & & \\
\hline Lateral habenula & ++++ & + & + & ++ & ++ & + & + & - \\
\hline Medial habenula & ++++ & ++ & +++ & +++ & +++ & + & ++++ & - \\
\hline
\end{tabular}




\begin{tabular}{|c|c|c|c|c|c|c|c|c|}
\hline \multicolumn{9}{|l|}{ Thalamus } \\
\hline Anterodorsal nucleus & +++ & ++ & +++ & +++ & ++ & ++ & + & - \\
\hline Reticular nucleus & +++ & ++ & ++ & ++ & ++ & ++ & + & - \\
\hline Centromedial nucleus & +++ & ++ & ++ & ++ & ++ & ++ & + & - \\
\hline $\begin{array}{l}\text { Laterodorsal nucleus, } \\
\text { dorsomedial part }\end{array}$ & +++ & ++ & +++ & +++ & ++ & ++ & + & - \\
\hline $\begin{array}{l}\text { Laterodorsal nucleus, } \\
\text { ventrolateral part }\end{array}$ & +++ & ++ & ++ & ++ & ++ & ++ & + & - \\
\hline \multicolumn{9}{|l|}{ Hypothalamus } \\
\hline Dorsomedial nucleus & +++ & + & + & ++ & +++ & + & + & + \\
\hline Ventromedial nucleus & +++ & + & + & +++ & +++ & + & + & ++ \\
\hline Arcuate nucleus & ++++ & - & +++ & +++ & n.d & + & +++ & - \\
\hline Paraventricular nucleus & ++++ & + & +++ & ++ & +++ & + & ++++ & - \\
\hline Supraoptic nucleus & ++++ & - & +++ & +++ & +++ & - & ++++ & - \\
\hline \multicolumn{9}{|l|}{ Brainstem } \\
\hline Red nucleus & + & n.d & + & n.d & + & n.d & + & - \\
\hline Ventral tegmental area & ++ & - & $\begin{array}{c}+ \\
\text { abundant } \\
\text { fibres }\end{array}$ & +++ & $\begin{array}{l}\text { abundant } \\
\text { fibres }\end{array}$ & - & n.d & - \\
\hline Substantia nigra & & & $\begin{array}{c}\text { abundant } \\
\text { fibres }\end{array}$ & & $\begin{array}{c}\text { abundant } \\
\text { fibres }\end{array}$ & & & \\
\hline Compact part & ++ & - & +++ & +++ & + & - & + & - \\
\hline Reticular part & + & - & - & +++ & - & - & - & - \\
\hline Dorsal raphe nucleus & +++ & + & + & ++ & ++ & + & +++ & +++ \\
\hline Pontine nuclei & +++ & ++ & +++ & ++ & ++ & + & ++ & + \\
\hline Locus coeruleus & n.d & + & n.d & ++ & n.d & + & n.d & ++ \\
\hline \multicolumn{9}{|l|}{ Cerebellum } \\
\hline Granule cell layer & +++ & +++ & +++ & +++ & +++ & +++ & - & - \\
\hline
\end{tabular}

The relative abundance of immunostained cell bodies is indicated as: "++++" very abundant (more than 2500 labeled elements $/ \mathrm{mm}^{2}$ ); "+++" abundant (1500-2500 labeled elements $\left./ \mathrm{mm}^{2}\right)$; "++" moderate expression (1000-1500 labeled elements $/ \mathrm{mm}^{2}$ ); "+" low expression (less than 1000 labeled elements $/ \mathrm{mm}^{2}$ ); "“" consistent absence of detectable staining; "n.d" not determined.

The relative densities of labeled mRNAs obtained by semiquantification of film autoradiograms are expressed as: "+++" very high (relative optical density higher than 0.5 ); "++" moderate (relative optical density from 0.35 to 0.5 ); "+" low (relative optical density lower than 0.35 ); "-" very low or undetectable; "n.d" not determined. 